Review

\title{
Cyclodextrin Multicomponent Complexes: Pharmaceutical Applications
}

\author{
Virginia Aiassa ${ }^{\dagger}$, Claudia Garnero ${ }^{\dagger}$, Marcela R. Longhi ${ }^{*}+{ }^{+}(\mathbb{D})$ and Ariana Zoppi ${ }^{\dagger}(\mathbb{C}$ \\ Unidad de Investigación y Desarrollo en Tecnología Farmacéutica, UNITEFA-CONICET, Departamento de \\ Ciencias Farmacéuticas, Facultad Ciencias Químicas, Universidad Nacional de Córdoba, Córdoba 5000, \\ Argentina; viraiassa@unc.edu.ar (V.A.); cgarnero@unc.edu.ar (C.G.); azoppi@unc.edu.ar (A.Z.) \\ * Correspondence: mrlonghi@unc.edu.ar \\ t These authors contributed equally to this work.
}

Citation: Aiassa, V.; Garnero, C.; Longhi, M.R.; Zoppi, A. Cyclodextrin Multicomponent Complexes: Pharmaceutical Applications. Pharmaceutics 2021, 13, 1099. https: / / doi.org/10.3390/ pharmaceutics13071099

Academic Editors: Paola Mura and Marzia Cirri

Received: 28 May 2021

Accepted: 15 July 2021

Published: 20 July 2021

Publisher's Note: MDPI stays neutral with regard to jurisdictional claims in published maps and institutional affiliations.

Copyright: (c) 2021 by the authors. Licensee MDPI, Basel, Switzerland. This article is an open access article distributed under the terms and conditions of the Creative Commons Attribution (CC BY) license (https:// creativecommons.org/licenses/by/ $4.0 /)$.

\begin{abstract}
Cyclodextrins (CDs) are naturally available water-soluble cyclic oligosaccharides widely used as carriers in the pharmaceutical industry for their ability to modulate several properties of drugs through the formation of drug-CD complexes. The addition of an auxiliary substance when forming multicomponent complexes is an adequate strategy to enhance complexation efficiency and to facilitate the therapeutic applicability of different drugs. This review discusses multicomponent complexation using amino acids; organic acids and bases; and water-soluble polymers as auxiliary excipients. Special attention is given to improved properties by including information on the solubility, dissolution, permeation, stability and bioavailability of several relevant drugs. In addition, the use of multicomponent CD complexes to enhance therapeutic drug effects is summarized.
\end{abstract}

Keywords: auxiliary agents; complexation efficiency amino acids; organic acids; organic bases; water-soluble polymers

\section{Introduction}

Cyclodextrins (CDs) are a family of macromolecules composed of $\alpha$-1,4-linked Dglucopyranoside subunits obtained by enzymatic degradation of starch [1]. Their structure resembles a truncated cone, with a somewhat lipophilic central cavity and an external hydrophilic surface. Antoine Villiers discovered the crystalline dextrins that were later recognized as CDs, and he published the first reference to these compounds in 1891 [2]. The most common natural CDs are $\alpha \mathrm{CD}, \beta C D$ and $\gamma \mathrm{CD}$ (Figure 1), consisting of 6, 7 and 8 D-glucose units, and they are the only ones used for pharmaceutical applications. Several researchers have attempted to develop other $\mathrm{CD}$ derivatives of pharmaceutical interest. Chemically modified CDs can be obtained from the introduction of different functional groups at the 2, 3 and 6-hydroxyl groups of the glucose residues. These include, for example, the hydroxypropyl, methylated and sulfobutylether $\beta$-cyclodextrins $(\mathrm{HP} \beta C D, M \beta C D$, SBE $\beta C D)$, and (2-hydroxy)propyl- $\gamma$-cyclodextrin (HP $\gamma \mathrm{CD})$, among others [3].

CDs have been used in pharmaceutical formulations since the 1970s. The first pharmaceutical product containing CD, marketed in Japan in 1976, was Prostarmon E ${ }^{\mathrm{TM}}$ (prostaglandin E2: $\beta C D$ ) [4]. Currently, there are various commercial formulations containing CDs. In addition, CD monographs are included in various pharmacopoeias and are accepted as pharmaceutical excipients by various regulatory agencies. The special interest for CDs in the field of pharmaceutical applications is due to their ability to modulate several properties affecting the performances and therapeutic profiles of drugs. CDs can be used to enhance the aqueous solubility of poorly soluble drugs; increase drug permeability through biological membranes; improve drug bioavailability and stability; reduce adverse drug reactions, such as gastrointestinal or ocular irritation and other side effects; convert liquids and oils into free-flowing powders; reduce evaporation and stabilize flavors; improve palatability and handling; and prevent admixture incompatibilities [5]. It should be 
noted that the modified $\gamma$-CD sugammadex, developed by the pharmaceutical company Organon, is used as a drug to reverse the neuromuscular blockade induced by rocuronium and vecuronium in adults undergoing surgery [6].

(A)
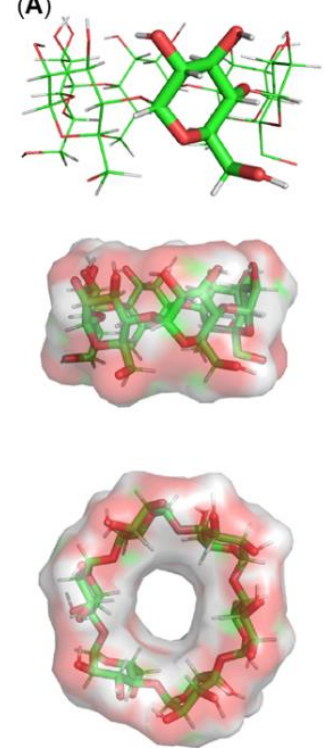

(B)
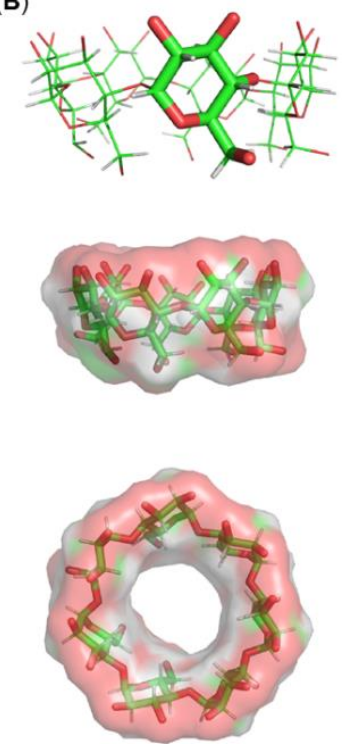

(C)
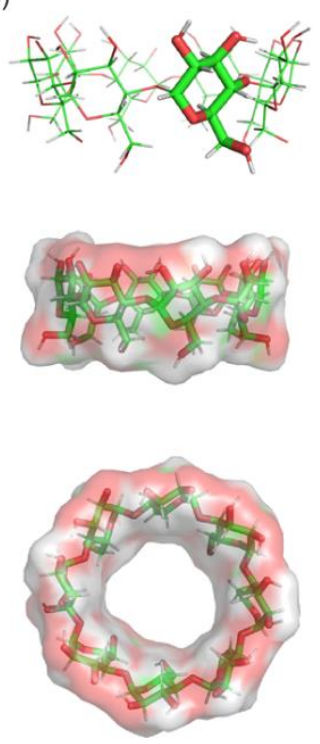

Figure 1. Molecular structures and three-dimensional side and top views of: $(A) \alpha C D,(B) \beta C D$ and (C) $\gamma \mathrm{CD}$. The surfaces shown represent the solvent-accessible surface areas (SASAs) in regard to water. Colors by atom-type indicate the regions of the molecule that are accessible (red: oxygen; grey: carbon). SASAs were calculated using cyclodextrin structures deposited in the Cambridge Crystallographic Data Centre under 1100537, 1107195 and 1126611 deposition numbers for $\alpha C D$, $\beta C D$ and $\gamma C D$, respectively. The image was prepared using Pymol v.2.1 and in-house developed Python scripts.

All these pharmaceutical applications are mostly related to the ability of CDs to form inclusion complexes. An inclusion complex is formed by interactions between guest (drug) and host (CD) molecules, and thus requires structural complementarity between the interacting compounds. A drug-CD complex that can be optimized with the addition of an auxiliary substance can be called a multicomponent or ternary complex. In these cases, a synergic effect is desired to allow the use of low concentrations of the non-drug compounds. The use of multicomponent complex formation with CDs and a third auxiliary substance has become more frequent in order to facilitate the therapeutic applicability of different drugs. The incorporation of small amounts of various additives, such as amino acids; organic acids and bases; and water-soluble polymers in aqueous complexation media can increase the complexation efficiency, which permits the use of considerably lower quantities of CDs, thereby optimizing the cost, toxicity and formulation volume in the final product [7-10]. These additives might also interact with CDs in order to improve and modulate the drugs' physicochemical and transport properties. This interaction can modulate in vitro and in vivo drug dissolution, thereby modifying the drug's pharmacokinetic profile. Moreover, it is possible to reduce other problematic behaviors of the drugs, such as their toxicological properties, by specifically selecting an auxiliary substance that will be added to the multicomponent complex. Regarding the methodological aspects, the techniques commonly used to obtain binary complexes can be used in the preparation of ternary ones in solid state. Methods such as blending, co-grinding, kneading, coevaporation/coprecipitation, freeze-drying, spray-drying and supercritical fluid technology have been used [8]. The method used for the multicomponent complex's preparation has significant impacts on the final product. Depending on the method selected, different parameters should be optimized, such as the intensity of mixing, mixing time, temperature and heating time. 
Since amino acids; organic acids and bases; and water-soluble polymers have some advantages over other excipients when used as auxiliary agents, this article reviews and tries to cover the most relevant multicomponent CD complexes obtained with these auxiliary compounds, along with their uses in the pharmaceutical field. Their applications in drug delivery are illustrated and discussed in depth by using specific examples reported in the literature. These examples support their use in the development of drug formulations with improved properties.

\section{Amino Acids as Auxiliary Agents}

Amino acids (AAs) present a series of adequate properties for pharmaceutical applications, such as a large variety of molecular structures and physicochemical properties, a wide scope of functional groups, low molecular weight and good solubility in aqueous media. In addition, AAs are generally regarded as safe and have great potential for interacting with CDs and drugs via hydrogen bonding with CDs and via electrostatic interactions and salt formation with drugs. Therefore, there is growing interest in utilizing AAs for multicomponent CD complex development to improve unfavorable drug properties. Several examples of multicomponent complexes of CD can be found in the literature in which AAs have been used as auxiliary agents not only to improve the solubility and dissolution rates of poorly soluble drugs, but also to allow the modulation of other drug properties. For example, AAs have shown their usefulness by increasing antimicrobial activity and reducing the toxicity of drugs [7,11].

Among the AAs that have been used to prepare multicomponent complexes, it is possible to mention glycine, cysteine, proline, arginine, lysine, aspartic acid and glutamic acid (Figure 2)-arginine being one of the AAs that has produced the best results in the formation of multicomponent complexes (Table 1, Figure 3). For example, Mura et al. studied the ability of several amino acids (arginine, isoleucine, lysine and valine) in combination with $\mathrm{HP} \beta C \mathrm{CD}$ to improve the solubility of naproxen, a poorly water-soluble drug. Arginine was the amino acid that allowed the greatest increase in drug solubility, showing a synergistic effect with HP $\beta C D$ [12]. In addition, the use of arginine in combination with HP $\beta C D$ improved naproxen's dissolution rate [13]. Similar results with respect to increased solubility and dissolution were obtained with other nonsteroidal anti-inflammatory drugs, such as lornoxicam, oxaprozin and zaltoprofen, by using a ternary complex with arginine and a $\mathrm{CD}(\beta \mathrm{CD}, \mathrm{HP} \beta C \mathrm{C}$ or $\mathrm{M} \beta C D)$ [14-16]. Besides, arginine was the best tertiary component in regard to improving the solubility and dissolution performance of etodolac, another nonsteroidal anti-inflammatory drug, in the presence of HP $\beta C D$ [17]. Using computational modeling, the authors demonstrated that arginine forms a bridge between the drug and the HP $\beta C D$, through hydrogen bonding and electrostatic interactions, which led to an increase in the stability of the complex. By means of molecular modeling studies, other reports also concluded that arginine plays an important role in the formation of drug-CD multicomponent complexes, and demonstrated the ability of arginine to establish hydrogen bonds with the macromolecule $[18,19]$.

Singh et al. studied combinations of different auxiliary agents (lactose, polyvinylpyrrolidone K-30, poloxamer-188, sodium lauryl sulphate and arginine) with HP $\beta C D$ to select the most appropriate substance with which to prepare a ternary complex of glyburide. Glyburide is a poorly water-soluble drug used as a hypoglycemic agent. The drug's solubility was studied in an aqueous solution and in a $\mathrm{pH} 7.5$ phosphate buffer system; in both media, the ternary complex glyburide-HP $\beta C D$-arginine presented superior solubility compared with the other binary and ternary systems. The stability constant values reported at $\mathrm{pH}=7.5$ were $100 \mathrm{M}^{-1}$ for the binary complex and $360 \mathrm{M}^{-1}$ for the ternary one [20]. Repaglinide and nateglinide belong to the meglitinide class of blood glucose-lowering drugs. In order to improve the solubilities and dissolution rates of these Biopharmaceutical Classification System (BCS) class II drugs, the effects of different auxiliary agents were studied in combination with HP $\beta C D$. Arginine was the best candidate for forming ternary complexes with both drugs. The authors found the following values for 
stability constant and complexation efficiency: repaglinide-HP $\beta C D, 333 \mathrm{M}^{-1}$ and 0.025 ; repaglinide-HP $\beta C D$-arginine, $4407 \mathrm{M}^{-1}$ and 0.340 ; nateglinide-HP $\beta C D, 382 \mathrm{M}^{-1}$ and 0.435; nateglinide-HP $\beta C D$-arginine, $464 \mathrm{M}^{-1}$ and 0.526 [21,22].

Cefixime is a third-generation cephalosporin that has poor aqueous solubility and variable bioavailability. Jadhav et al. proved that the formation of cefixime-CD-arginine ternary complexes constitutes a good strategy to enhance the solubility and dissolution of the drug. The use of arginine allows increasing the slope, stability constant and complexation efficiency with both $C D s(\beta C D$ and $H P \beta C D)$. The binary and ternary systems prepared by the spray drying method showed better dissolution rates than the drug alone; the ternary complex with HP $\beta C D$ showed the best results [23]. Rifampicin is another antibiotic drug with low water solubility and variable bioavailability. Dan Córdoba et al. demonstrated that multicomponent complex formation with $\beta C D$ and arginine was an adequate approach to improving not only the solubility and the dissolution profile of rifampicin, but also its antibiofilm activity against methicillin-sensitive and methicillin resistant Staphylococcus aureus bacterial strains. Using theoretical studies, the authors found that arginine can establish hydrogen bond interactions with the drug and $\beta C D$, which leads to an increase in the stability of the multicomponent complex [24].

Conde Penedo et al. studied the effect of a combination containing HP $\beta C D$, chitosan and arginine on the solubility and corneal permeability of riboflavin. The pure drug has a solubility of $0.12 \mathrm{mg} / \mathrm{mL}$, whereas in the presence of HP $\beta C D$ or HP $\beta C D$-chitosan-arginine, the solubility was 0.35 or $0.78 \mathrm{mg} / \mathrm{mL}$, respectively. In addition, this combination had a synergistic effect on the permeability of the drug with the absence of toxicity [25].

Mora et al. prepared a 1-2-3 dehydroepiandrosterone- $\alpha \mathrm{CD}-$ glycine ternary complex to improve the solubility and bioavailability of this drug. This complex showed better dissolution properties and improved pharmacokinetic parameters in human volunteers, as compared with the unmodified drug. The area under curve $(59 \pm 20$ and $29 \pm 17 \mathrm{ng} / \mathrm{mL} . \mathrm{h})$ and the peak serum concentration $\left(C_{\max } 10.9 \pm 6.3\right.$ and $\left.4.8 \pm 3.8 \mathrm{ng} / \mathrm{mL}\right)$ for the complex were higher than those obtained with the drug alone, and the time to reach $\mathrm{C}_{\max }$ was reduced ( $\mathrm{T}_{\max } 0.5 \pm 0.2$ and $2.2 \pm 0.9 \mathrm{~h}$ for the complex versus drug alone, respectively) [26].

Piel et al. evaluated the effect of lysine in combination with $\beta C D$ and $\gamma C D$ on the aqueous solubility of nimesulide, a nonsteroidal anti-inflammatory drug with very poor water solubility. The solubility of nimesulide in the presence of lysine $-\beta C D$ was $6.59 \mathrm{mg} / \mathrm{mL}$, and in the presence of lysine $-\gamma \mathrm{CD}$ it was $19.07 \mathrm{mg} / \mathrm{mL}$. These values are greater than the ones obtained using binary systems (nimesulide-lysine $4.45 \mathrm{mg} / \mathrm{mL}$, nimesulide- $\beta C D$ $0.025 \mathrm{mg} / \mathrm{mL}$ and nimesulide $-\gamma \mathrm{CD} 0.022 \mathrm{mg} / \mathrm{mL}$ ), evidencing that CDs and lysine have a synergistic effect on nimesulide's aqueous solubility. Additionally, the solubility of the complexes prepared by precipitation was measured in water and at different $\mathrm{pH}$ levels. The nimesulide- $\beta C D$-lysine complex was the most soluble [27]. For example, at $\mathrm{pH} 6.8$, the solubility was $2.37 \mathrm{mg} / \mathrm{mL}$ for the nimesulide- $\beta C D$-lysine complex, compared with $0.015 \mathrm{mg} / \mathrm{mL}$ for pure nimesulide and $1.71 \mathrm{mg} / \mathrm{mL}$ for the complex nimesulide-lysine$\gamma \mathrm{CD}$ [27]. In another work, Piette et al. used a multicomponent system with lysine and $\mathrm{HP} \beta C D$ to prepare oral and intravenous solutions of Ro 28-2653, a synthetic inhibitor of matrix metalloproteinases in development, which exhibits poor water solubility. These systems increased the drug solubility of Ro 28-2653. In addition, the absolute bioavailability (compared with the intravenous solution) was about 10 times higher for the drug that was orally administered as a multicomponent complex in solution than for a suspension of the drug alone. The solution showed a higher $C_{\max }(51.8 \mathrm{vs} .4 .8 \mu \mathrm{g} / \mathrm{mL})$ and a lower $\mathrm{T}_{\max }$ ( 3.6 vs. $12.3 \mathrm{~h}$ ) versus the drug alone, respectively [28]. Furthermore, some investigations showed that the incorporation of lysine increases the inclusion efficiency of drugs, such as piroxicam and ketoprofen, into CDs when supercritical fluid technology is used for the complex preparations $[29,30]$.

Cerutti et al. determined that the formation of a multicomponent complex between nifedipine, a calcium-channel blocking agent, $\beta C D$ and aspartic acid was an adequate strategy for improving the solubility and dissolution profile of the drug. Pure nifedipine 
showed a maximum of $30 \pm 2 \%$ drug dissolution at $180 \mathrm{~min}$, compared with the values for the binary and multicomponent complexes, which were $66 \pm 6 \%$ and $95.0 \pm 0.5 \%$, respectively [31]. Norfloxacin, a fluoroquinolone antibiotic, is a weak base drug that has low solubility in water. To overcome this problem, Ponce Ponte et al. studied the possibility of preparing multicomponent complexes using AAs (glutamic acid, lysine and proline) and $\mathrm{HP} \beta C D$. In this case, glutamic acid was the best candidate with which to form ternary complexes [32]. Chloramphenicol is an antibacterial drug that is slightly soluble in water and has serious side effects. Aiassa et al. investigated different multicomponent complexes of this drug with $\mathrm{CDs}(\beta C D$ and $\gamma C D)$, AAs (glycine and cysteine) and $N$-acetylcysteine, the $\mathrm{N}$-acetyl derivative of the amino acid cysteine. All the multicomponent complexes studied increased the solubility of the drug and proved to be less toxic against leukocytes than the pure drug. In addition, the multicomponent complexes with both $\mathrm{CDs}$ and $\mathrm{N}$-acetylcysteine were more active against $S$. aureus biofilms than the drug alone $[11,33,34]$. Ketoconazole is an imidazole antifungal drug with low solubility. Zoppi et al. investigated the possibility that proline and $\mathrm{N}$-acetylcysteine act as ternary complexation agents for the binding of ketoconazole with $\beta C D$. The increases in drug solubility found for these complexes were of 54, 65 and 459-fold for the binary and ternary complexes containing proline or $\mathrm{N}$-acetylcysteine, respectively. Both multicomponent complexes showed antifungal activity significantly greater than the drug alone or the binary complex [35,36]. In addition, the complex containing $\mathrm{N}$-acetylcysteine was able to decrease the fungal viability in the biofilms of $C$. albicans.

From the analysis of these works, it is evident that proper selection of the auxiliary agent allows one to not only increase the solubility but also to modify other properties of the drug.<smiles>NCC(=O)O</smiles><smiles>NC(C[Hg])C(=O)O</smiles>

(C)<smiles>O=C(O)C1CCCN1</smiles>

(D)<smiles>N=C(N)NCCCC(N)C(=O)O</smiles><smiles>NC(CC(=O)O)C(=O)O</smiles><smiles>NCCCCC(N)C(=O)O</smiles><smiles>NC(CCC(=O)O)C(=O)O</smiles>

Figure 2. Molecular structures of: (A) glycine, (B) cysteine, (C) proline, (D) arginine, (E) lysine, (F) aspartic acid and (G) glutamic acid. 
Table 1. Summary of some reports on ternary complexes of CDs with arginine, including the improvements in pharmaceutical properties.

\begin{tabular}{|c|c|c|c|c|c|c|}
\hline Ternary System & $\begin{array}{l}\text { Molar } \\
\text { Ratio }\end{array}$ & $\begin{array}{l}\text { Preparation } \\
\text { Method }\end{array}$ & Solubility & Dissolution & $\begin{array}{c}\text { Other } \\
\text { Properties }\end{array}$ & Reference \\
\hline $\begin{array}{l}\text { naproxen-HP } \beta C D- \\
\text { arginine }\end{array}$ & $1: 1: 1$ & $\begin{array}{l}\text { co-grinding } \\
\text { coevaporation }\end{array}$ & $\begin{array}{l}\text { synergistic action between } \\
\text { HP } \beta C D \text { and arginine with } \\
\text { 13-fold solubility } \\
\text { increment }\end{array}$ & $\begin{array}{l}\text { superior performance of } \\
\text { coevaporate complex } \\
\text { with } 15 \text { times increase } \\
\text { in DE }\end{array}$ & & {$[12,13]$} \\
\hline lornoxicam- $\beta C D$-arginine & $1: 2: 1$ & freeze-drying & $\begin{array}{l}\text { freeze-dried complex } \\
\text { showed the higher } \\
\text { solubility saturation in } \\
\text { different buffer media }\end{array}$ & $\begin{array}{l}\text { freeze-dried complex } \\
\text { exhibits }>95 \% \\
\text { dissolution after } 20 \mathrm{~min}\end{array}$ & & [14] \\
\hline $\begin{array}{l}\text { oxaprozin-M } \beta \mathrm{CD}- \\
\text { arginine }\end{array}$ & $1: 1: 1$ & $\begin{array}{l}\text { co-grinding } \\
\text { coevaporation } \\
\text { kneading }\end{array}$ & $\begin{array}{l}\text { 4.5-fold solubility } \\
\text { increment compared with } \\
\text { the binary complex at } \mathrm{pH} \\
6.8\end{array}$ & $\begin{array}{l}\text { co-ground complex } \\
\text { showed better } \\
\text { performance }(\mathrm{DE} 60= \\
83) \text { compared with the } \\
\text { oxaprozin:M } \beta C D \\
\text { complex }(\mathrm{DE} 60=6.8)\end{array}$ & & [15] \\
\hline $\begin{array}{l}\text { zaltoprofen- } \beta C D \text { - } \\
\text { arginine } \\
\text { zaltoprofen-HP } \beta C D- \\
\text { arginine }\end{array}$ & $1: 1: 1$ & $\begin{array}{l}\text { spray-drying } \\
\text { coevaporation }\end{array}$ & $\begin{array}{c}\text { spray-dried ternary } \\
\text { complex with HP } \beta C D \\
\text { showed the higher } \\
\text { solubility saturation in } \\
\text { water and buffer pH } 1.2\end{array}$ & $\begin{array}{l}\text { Both, the spray-dried } \\
\text { and co-ground ternary } \\
\text { complex with } \beta C D \text { and } \\
\text { HP } \beta C D \text { showed 14- } \\
\text { and } 15 \text {-fold increase in } \\
\text { dissolution, respectively } \\
\text { compared with pure } \\
\text { drug }\end{array}$ & & {$[16]$} \\
\hline $\begin{array}{c}\text { etodolac-HP } \beta C D- \\
\text { arginine }\end{array}$ & 1:1:1 & $\begin{array}{l}\text { spray-drying } \\
\text { coevaporation }\end{array}$ & $\begin{array}{c}\text { Spray-dried and } \\
\text { coevaparate ternary } \\
\text { complex showed an } \\
\text { increment of 163- and } \\
\text { 100-fold, respectively, in } \\
\text { water with respect to } \\
\text { saturation solubility of } \\
\text { pure drug }\end{array}$ & $\begin{array}{l}\text { Spray-dried and } \\
\text { coevaparate ternary } \\
\text { complex exhibits an } \\
\text { increase in percent drug } \\
\text { release of 19- and } \\
\text { 20-fold, respectively, } \\
\text { with respect to pure } \\
\text { etodolac. }\end{array}$ & & [17] \\
\hline $\begin{array}{c}\text { glyburide-HP } \beta C D- \\
\text { arginine }\end{array}$ & 1:1:0.5 & co-grinding & $\begin{array}{l}\text { ternary complex showed } \\
\text { higher solubility in both } \\
\text { aqueous media } \\
\text { and buffer pH } 7.5\end{array}$ & $\begin{array}{l}\text { ternary complex } \\
\text { exhibits significant } \\
\text { improvement in the } \\
\text { dissolution profile } \\
\text { compared with the pure } \\
\text { drug in unbuffered } \\
\text { aqueous media }\end{array}$ & & [20] \\
\hline $\begin{array}{l}\text { repaglinide-HP } \beta C D \text { - } \\
\text { arginine }\end{array}$ & $1: 1: 1$ & $\begin{array}{l}\text { coevaporation } \\
\text { kneading }\end{array}$ & $\begin{array}{l}\text { coevaporate complex } \\
\text { showed maximum } \\
\text { increase in solubility of } \\
\text { drug ( } 475 \text {-fold) }\end{array}$ & $\begin{array}{l}\text { ternary complexes } \\
\text { showed enhanced } \\
\text { dissolution rate }\end{array}$ & & [21] \\
\hline $\begin{array}{l}\text { nateglinide-HP } \beta C D \text { - } \\
\text { arginine }\end{array}$ & 1:1:1 & $\begin{array}{c}\text { kneading } \\
\text { coevaporation } \\
\text { spray-drying }\end{array}$ & $\begin{array}{l}\text { ternary complexes } \\
\text { showed higher solubility } \\
\text { in both aqueous media } \\
\text { and buffer pH } 1.2\end{array}$ & $\begin{array}{l}\text { ternary complexes } \\
\text { showed better } \\
\text { performance }(\mathrm{DE} 5=22) \\
\text { compared with the drug } \\
\text { alone }(\mathrm{DE} 5=6.6)\end{array}$ & & {$[22]$} \\
\hline $\begin{array}{c}\text { cefixime- } \beta C D \text {-arginine } \\
\text { cefixime-HP } \beta C D- \\
\text { arginine }\end{array}$ & & spray-drying & $\begin{array}{l}\text { ternary complex showed } \\
\text { better drug solubility }\end{array}$ & $\begin{array}{l}\text { ternary complex with } \\
\text { HP } \beta C D \text { exhibit better } \\
\text { performance }(\mathrm{DE} 2=25) \\
\text { compared with the drug } \\
\text { alone }(\mathrm{DE} 2=0.75)\end{array}$ & & {$[23]$} \\
\hline rifampicin- $\beta C D$ - arginine & $1: 1: 1$ & freeze-drying & $\begin{array}{l}\text { ternary complex showed } \\
\text { an increase in the drug } \\
\text { solubility }\end{array}$ & $\begin{array}{l}\text { ternary complex } \\
\text { showed } \\
\text { an increase in the } \\
\text { dissolved percentage of } \\
\text { the drug } \\
\text { (53\% versus } 25 \% \text { for } \\
\text { drug alone) }\end{array}$ & $\begin{array}{l}\text { higher } \\
\text { antibiofilm } \\
\text { activity with } \\
\text { respect to } \\
\text { pure } \\
\text { rifampicin }\end{array}$ & [24] \\
\hline
\end{tabular}


<smiles>COc1ccc2cc(C(C)C(=O)O)ccc2c1</smiles>

(c)<smiles>O=C(O)CCc1nc(-c2ccccc2)c(-c2ccccc2)o1</smiles>

(E)
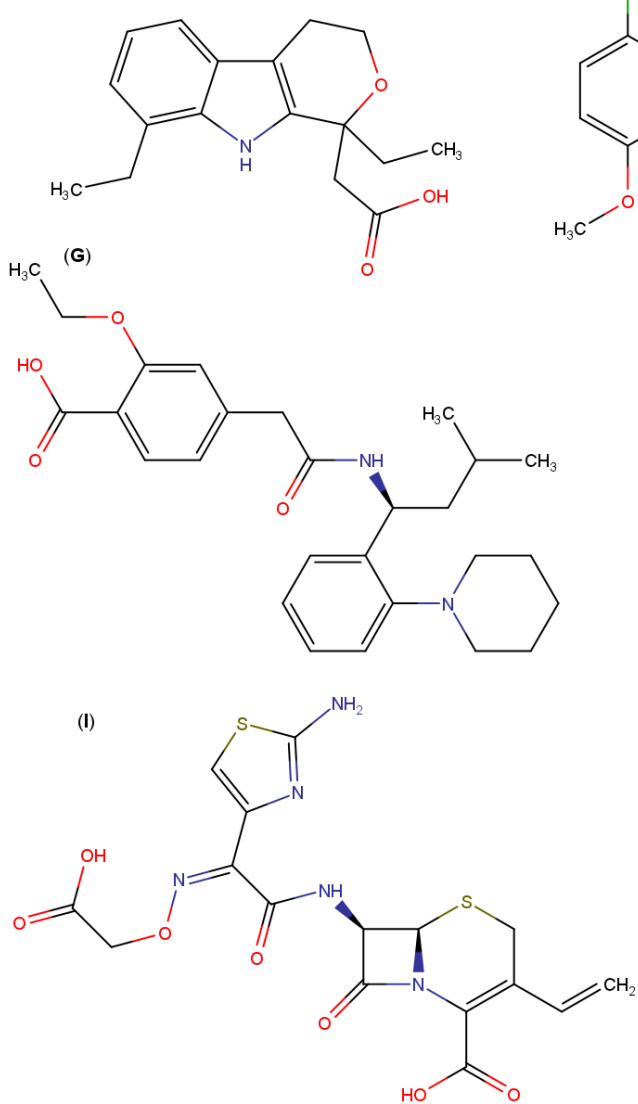<smiles>CN1C(C(=O)Nc2ccccn2)=C(O)c2sc(Cl)cc2S1(=O)=O</smiles>

(D)<smiles>CC(C(=O)O)c1ccc2c(c1)CC(=O)c1ccccc1S2</smiles><smiles>COc1ccc(Cl)cc1C(=O)NCCc1ccc(S(=O)(=O)NC(=O)NC2CCCCC2)cc1</smiles>
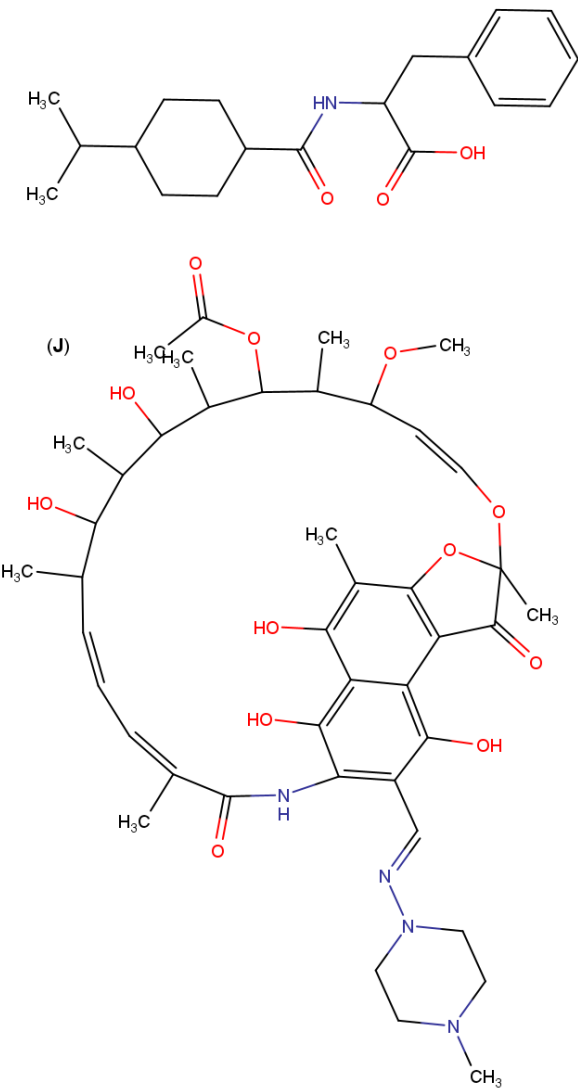

Figure 3. Molecular structures of: (A) naproxen, (B) lornoxicam, (C) oxaprozin, (D) zaltoprofen, (E) etodolac, $(\mathbf{F})$ glyburide, $(\mathbf{G})$ repaglinide, $(\mathbf{H})$ nateglinide, $(\mathbf{I})$ cefixime and $(\mathrm{J})$ rifampicin. 


\section{Organic Acids as Auxiliary Agents}

Multicomponent complexes with CDs and different acids have been studied to improve the properties by orders of magnitude of basic drugs in relation to classic drug-CD binary complexes. The ternary complexes are obtained by adding certain low-molecularweight acids, such as hydroxy carboxylic acids (Figure 4) [9,37,38], to the binary complexes composed of the respective drugs and CDs. These auxiliary acid substances, together with the CDs, improve the physicochemical, chemical and transport properties, and therefore provide advantages in terms of bioavailability and pharmaceutical use [38].

The mechanism of action of weak acids allows stabilizing a ternary complex through a combination of interactions (hydrogen bonding, salt formation and electrostatic interactions) depending on the nature and structural characteristics of the molecules. It is important to note that these acids are compounds rich in hydrophilic groups distributed along their molecular structures that have little affinity for the cavity of the CD and not contribute to the inclusion; instead, they can play the role of cross-linker between the basic drug and the CD [37-40]. Consequently, a drug's solubility can be improved, and the drug's crystallinity is reduced, thereby accelerating its dissolution rate.

Although the total solubility achieved usually increases, in some cases a decrease in the complex stability constant was observed. The reason was that the higher drug solubility produced by an increased drug ionization in the presence of the acid resulted in less affinity for the apolar CD cavity [41,42].

Among the hydroxy acids, the citric, gluconic, tartaric, lactic and malic acids are reported to be promising ternary candidates due to their potential ability to interact with CD molecules by forming hydrogen bonds with their numerous hydroxyl groups $[9,43]$.

Several studies on the ternary complexes of citric acid with CDs have been reported (Table 2, Figure 5). In the case of econazole nitrate, a salt commonly used in pharmaceutical formulations due to its great solubility, it was determined that the ternary system obtained by adding of an equimolar amount of citric acid to the SBE $\beta C D$ binary complex produces a considerable increase in solubility [40]. Econazole nitrate's solubility in the ternary system was $5.83 \mathrm{mg} / \mathrm{mL}$; this value is higher than the sum of the maximum solubility obtained for each binary system, evidencing the synergy between SBE $\beta C D$ and citric acid for the solubility improvement. In addition, this increase was reflected in a modified dissolution assay that simulated the oral cavity conditions, which showed an efficiency increase of 66-fold for the co-ground system compared with the drug alone. Moreover, the ternary complex showed significantly higher antimycotic efficacy against selected Candida strains than the drug alone [44]. Taking into account its superior properties, Jug et al. proposed the equimolar ternary system as a suitable product with therapeutic effectivity for the preparation of a novel mucoadhesive buccal formulation that has potential for drug delivery into the oral cavity, and it could improve on the existing therapy for oral candidosis $[40,44]$. Furthermore, ternary complexes of carvedilol with $\beta C D$ and citric acid prepared at 1:2:2 molar ratios, respectively, by physical mixture, kneading and spray-drying, were reported. A notable solubility increase of 110 -fold for the complex obtained by spray-drying was determined. In addition, this spray-dried complex showed greater efficiency for the complex formation than the kneaded complex. Tablets formulated with these complexes exhibited a significant improvement in dissolution compared with tablets containing the pure carvedilol, by achieving $100 \%$ release in $5 \mathrm{~min}$. Therefore, this strategy is suitable for formulating mouth-dissolving tablets to overcome the first-pass metabolism of the drug and consequently improve its bioavailability [45]. Interestingly, Zhang et al. demonstrated the capacity of the clarithromycin- $\beta C D$-citric acid complex prepared by lyophilization, in a molar ratio of 1:1:1, to enhance the drug dissolution rate in basic media at $\mathrm{pH} 6.8$. After oral administration of this ternary complex in beagle dogs, the authors suggested that the bioavailability of clarithromycin could be slightly improved by complexation with $\beta C D$ and citric acid, due to the enhanced drug absorption in the duodenum, which was attributed to more of the drug being dissolved in the intestine and then available for immediate absorption [46]. 
In addition, multicomponent complexation via addition of hydroxy acids significantly improved cinnarizine's solubility and the complexation efficiency of HP $\beta C D$. Among the ternary systems containing 1:1:1 molar ratios of drug-CD-hydroxy acid (citric acid or tartaric acid), the one prepared with tartaric acid via co-evaporation method increased the aqueous solubility of cinnarizine by 1223 -fold [42]. The mechanisms through which the tartaric acid-CD ternary complexes improve the drug solubility have been extensively discussed in several reports. Aldawsari et al. reported that the combination oftartaric acid and HP $\beta C D$ act as solubilizing agents for dapoxetine hydrochloride, a weakly basic drug with $\mathrm{pH}$-dependent solubility that could limit its dissolution in physiologic neutral fluids. The $\mathrm{pH}$-modifying role of tartaric acid enhanced solubility, which was explained on the basis of a stronger modulating effect on the $\mathrm{pH}$ of the microenvironment around the drug particles [47]. Complexation of iloperidone, an atypical antipsychotic drug, with $\mathrm{HP} \beta C D$ and tartaric acid, afforded a significant solubility increase of c.a. 17-fold (improved to a maximum of $200 \mu \mathrm{g} / \mathrm{mL}$ ), and a better and faster dissolution profile, indicating the auxiliary roles of tartaric acid in increasing hydrophilicity and hydrogen bond formation of the ternary complex. A considerable reduction in the crystallinity of the drug was derived from intermolecular interactions with HP $\beta C D$ and tartaric acid, which could be associated with the enhanced solubility given to iloperidone. This could result in enhanced bioavailability [38]. In addition, Yuvaraja et al. showed that the ternary system formed with $\mathrm{HP} \beta C D$ and tartaric acid was notably more effective at enhancing the solubility of carvedilol, a cardiovascular drug that is basic in nature, than the binary system with $\mathrm{HP} \beta C D$. The solubility enhancement factor found was 340 , which could be associated with the ionization process of carvedilol in the presence of tartaric acid. Moreover, this auxiliary agent increases the dissolution rate via control of the $\mathrm{pH}$ in the microenvironment [48].

Rakkaew et al. studied ternary complexes of haloperidol—an antipsychotic drug that is a weak base with very low aqueous solubility - with $\beta C D$ and organic acids in different media. Tartaric, lactic and succinic acids were used to prepare the ternary complexes. In citrate buffer, $\mathrm{pH} \mathrm{3,} \mathrm{tartaric} \mathrm{and} \mathrm{lactic} \mathrm{acids} \mathrm{substantially} \mathrm{increased} \mathrm{drug} \mathrm{solubility,}$ which was attributed to unionized species of acid that interacted with haloperidol and $C D$ by forming hydrogen bonds with the hydroxyl groups of $\beta C D$, which enhanced the solubilization capacity. In particular, the lactic acid produced the greatest binding strength and solubilization efficacy for the ternary complexes [37]. Afterwards, Chantasart and Rakkaew investigated different preparation methods of dry $\beta C D$-based ternary complexes of haloperidol and lactic acid for drug delivery purposes. The ternary complex prepared by freeze-drying showed a higher inclusion yield than those prepared by solvent evaporation and physical mixing. The ${ }^{1} \mathrm{H}$ NMR studies confirmed that haloperidol interacts with the carboxyl and hydroxyl groups of lactic acid and $\mathrm{CD}$ inside and outside the cavity by hydrogen bonding or van der Waals interactions. In addition, drug amorphization was proven to occur due to the freeze-drying process, which significantly enhanced drug release. Complexes prepared using this technique could have superior haloperidol bioavailability, and may be useful in optimized carrier systems for nasal and transdermal delivery [49].

In another study, the ability of several acidic compounds to improve the formation of miconazole complexes with several CDs using supercritical carbon dioxide processing was reported [50]. The acids were able to promote drug inclusion, as shown by miconazole$\mathrm{HP} \gamma \mathrm{CD}$-tartaric acid/malic acid, and miconazole-HP $\beta C D$-tartaric acid, which achieved nearly complete inclusion. The hydroxypropylated CDs evidenced better results than native CDs. In particular, the presence of miconazole maleate salt was found for complexes containing maleic acid. Interestingly, these complexes were stable for up to one year. The complexes obtained with tartaric acid provided the maximum drug dissolution improvement. The best results were obtained with miconazole-HP $\gamma \mathrm{CD}$-tartaric acid in relation to miconazole alone. Subsequently, the relevant pharmacokinetic parameters of this ternary complex after oral administration were determined in pigs [51]. The complex formulation evidenced better absorption efficacy compared with capsules of miconazole alone, indicating higher relative bioavailability in an oral dosage form. 
Analysis of the data in the literature showed that synergistic effects on the solubility of multicomponent complexes are obtained by adding appropriate organic acids as auxiliary agents. The effects of several multicomponent complexes on econazole, an antifungal base-type drug that is poorly soluble in water, were researched. Various $C D(\alpha C D, \beta C D$, $\gamma \mathrm{CD}$ and $\mathrm{HP} \beta \mathrm{CD}$ ) and hydroxy acid (tartaric, citric, gluconic, malic and lactic acids) combinations were studied. The multicomponent systems containing $\alpha \mathrm{CD}$ were the best, as they produced the highest improvements in econazole solubility with almost all the various acid combinations. In particular, the system with $\alpha \mathrm{CD}$ and malic acid in a 1:1:1 molar ratio was the most effective combination. It synergistically enhanced the aqueous drug solubility 2560-fold with respect to the drug itself and to 20-fold with respect to the binary complex [52]. Nuclear magnetic resonance (NMR) experiments and molecular modelling studies evidenced the complex formation with malic acid that involved interactions with the primary hydroxyl groups of $\alpha \mathrm{CD}$ molecules [53]. Moreover, the synergic effect of the acids depended on the $C D$ type in all the ternary systems examined. For example, citric acid showed 2480, 1540, 2460 and 2440-fold solubility enhancements with $\alpha \mathrm{CD}, \gamma \mathrm{CD}, \beta C D$ and $\mathrm{HP} \beta C D$, respectively, in comparison to econazole alone. Due to the drug solubility enhancements produced by the multicomponent systems, the ternary solid products showed faster dissolution rates than those of the drug alone, confirming their higher effectiveness [52]. Furthermore, Ribeiro et al. demonstrated the synergistic effect of tartaric acid and $C D$ on enhancing the solubility of vinpocetine, which was related to a combined strategy of $\mathrm{CD}$ complexation and drug ionization. In fact, the formation of soluble multicomponent complexes increased the solubility of vinpocetine of $5 \mu \mathrm{g} / \mathrm{mL}$ to $5.80 \mathrm{mg} / \mathrm{mL}$; Moreover, an improvement in the complexation efficiency of $\beta C D$ and SBE $\beta C D$ was observed [41]. In addition, the combination of $\beta C D$ and citric acid produced a synergistic effect on clarithromycin's solubility: an almost 104-fold improved solubilization efficiency in relation to the intrinsic solubility of the pure drug [54].

Nevertheless, such ternary complexation was not always effective. For example, the ketoconazole- $\beta C D$-citric acid complex, in a 1:2:1 molar ratio, prepared via spray-drying method, showed a similar dissolution profile in a buffer solution at $\mathrm{pH} 5$ to the binary complex ketoconazole $-\beta C D$ prepared with the same molar ratio of $\beta C D$, although ketoconazole's solubility was better in the ternary system than in the binary $\mathrm{CD}$ complex. This was attributed to the ionization of the drug in the dissolution medium [55].

(A)<smiles>O=C(O)CC(O)(CC(=O)O)C(=O)O</smiles>

(B)<smiles>O=C(O)C(O)C(O)C(O)C(O)CO</smiles>

(C)<smiles>O=C(O)C(O)C(O)C(=O)O</smiles>

(G)
(D)<smiles>CC(O)C(=O)O</smiles>

(E)<smiles>O=C(O)CC(O)C(=O)O</smiles>

(F)<smiles>O=C(O)CCC(=O)O</smiles><smiles>O=C(O)/C=C\C(=O)O</smiles>

Figure 4. Molecular structures of: (A) citric acid, (B) gluconic acid, (C) tartaric acid, (D) lactic acid, (E) malic acid, (F) succinic acid and (G) maleic acid. 
Table 2. A summary of some reports on ternary complexes of cyclodextrins with citric acid (CA), including the pharmaceutical improvements.

\begin{tabular}{|c|c|c|c|c|c|c|}
\hline Ternary System & $\begin{array}{l}\text { Molar } \\
\text { Ratio }\end{array}$ & $\begin{array}{l}\text { Preparation } \\
\text { Method }\end{array}$ & Solubility & Dissolution & Other Properties & Reference \\
\hline $\begin{array}{c}\text { Econazole } \\
\text { nitrate-SBE } \beta C D-C A\end{array}$ & 1:1:1 & co-grinding & $\begin{array}{l}\text { synergistic action } \\
\text { between SBE } \beta C D \text { and } \\
\text { CA with } 21.2 \text { fold } \\
\text { solubility increment }\end{array}$ & $\begin{array}{l}\text { superior performance } \\
\text { of co-ground system } \\
\text { concentration } \\
\text { increased to } 479.07 \pm \\
11.3 \mu \mathrm{g} / \mathrm{mL} \text { after } 45 \\
\text { min }\end{array}$ & $\begin{array}{l}\text { higher antimycotic } \\
\text { activity with respect } \\
\text { to that of pure } \\
\text { Econazole }\end{array}$ & {$[40,44]$} \\
\hline Econazole- $\alpha \mathrm{CD}-\mathrm{CA}$ & 1:1:1 & & $\begin{array}{l}\text { highest solubilizing } \\
\text { power with } 2480 \text { fold } \\
\text { relative solubility } \\
\text { increment }\end{array}$ & & & \multirow{4}{*}[52]{} \\
\hline Econazole- $\gamma \mathrm{CD}-\mathrm{CA}$ & 1:1:1 & & $\begin{array}{l}1540 \text { fold relative } \\
\text { solubility increment }\end{array}$ & & & \\
\hline Econazole- $\beta C D-C A$ & 1:1:1 & & $\begin{array}{l}2460 \text { fold relative } \\
\text { solubility increment }\end{array}$ & & & \\
\hline Econazole-HP $\beta C D-C A$ & 1:1:1 & & $\begin{array}{l}2440 \text { fold relative } \\
\text { solubility increment }\end{array}$ & & & \\
\hline Carvedilol- $\beta$ CD-CA & $1: 2: 2$ & $\begin{array}{l}\text { kneading } \\
\text { spray-drying }\end{array}$ & $\begin{array}{l}\text { spray-dried complex } \\
\text { exhibits the higher } \\
\text { solubility saturation in } \\
\text { different buffer media }\end{array}$ & $\begin{array}{l}\text { spray-dried complex } \\
\text { exhibits significant } \\
\text { improvement in the } \\
\text { dissolution profile } \\
\text { compared with the } \\
\text { pure carvedilol }\end{array}$ & $\begin{array}{l}\text { spray-dried complex } \\
\text { is stable in exposition } \\
\text { to } 40^{\circ} \mathrm{C} \text { at } 75 \% \\
\text { relative humidity }\end{array}$ & {$[45]$} \\
\hline Clarithromycin- $\beta C D-C A$ & 1:1:1 & freeze-drying & & $\begin{array}{l}\text { freeze-dried complex } \\
\text { exhibits rapid and } \\
\text { enhanced dissolution } \\
\text { rate in basic media }\end{array}$ & $\begin{array}{l}\text { freeze-dried complex } \\
\text { exhibits slightly } \\
\text { improved absorption } \\
\text { in beagle dogs }\end{array}$ & [46] \\
\hline Clarithromycin- $\beta C D-C A$ & & $\begin{array}{l}\text { coevaporation } \\
\text { freeze-drying }\end{array}$ & $\begin{array}{l}\text { 104-fold solubility } \\
\text { increment }\end{array}$ & & & [54] \\
\hline Ketoconazole- $\beta C D-C A$ & $1: 2: 1$ & spray-drying & & $\begin{array}{l}\text { spray-dried complex } \\
\text { reach a dissolution } \\
\text { percentage close to } \\
100 \%\end{array}$ & & [55] \\
\hline
\end{tabular}<smiles>Clc1ccc(COC(Cn2ccnc2)c2ccc(Cl)cc2Cl)cc1</smiles><smiles>CCC(OC(=O)C1C(OC2CC(C)(OC)C(O)C(C)O2)[C@@H](C)C(OC2OC(C)CC(N(C)C)C2O)C1(C)OC)C(C)(O)C(O)C(C)C(=O)C(C)C</smiles>

(B)<smiles>COc1ccccc1OCCNCC(O)COc1cccc2[nH]c3ccccc3c12</smiles>

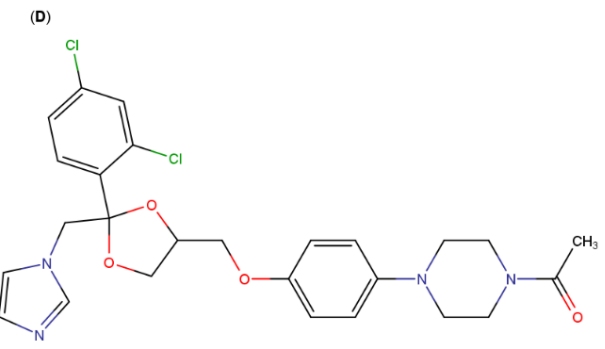

Figure 5. Molecular structures of: (A) econazole, (B) carvedilol, (C) clarithromycin and (D) ketoconazole. 


\section{Organic Bases as Auxiliary Agents}

Organic bases, whose structural diversity predetermines their magnitudes of effect upon drug- $\mathrm{CD}$ solution interactions, are being employed as tertiary components in ternary complexes, and they are used mainly when the drugs are acids. In these systems, the prominent role of electrostatic forces in the general interaction should be considered. Although the $\mathrm{CD}$ complexes obtained from non-ionized drugs have greater stability compared with their anionic analogues [10], the total solubility achieved and other properties of the drug such as chemical stability and bioavailability usually improve.

In the study carried out by Redenti et al. [10] on salt formation and concomitant complexation with $\mathrm{CD}$ to improve oral performance for acidic drugs, hydroxylamines were used with non-steroidal anti-inflammatory drugs. The aqueous solubility of piroxicam, a poorly soluble derivative of benzothiazine, is significantly increased by simultaneous salt formation with sodium, potassium and ammonium, and complexation with $\mathrm{\gamma CD}^{\mathrm{C}}$, achieving 4-7-fold and 2-4-fold solubility enhancements with respect to the drug itself and the binary complex, respectively [56].Simultaneous salt formation and complexation with $\beta C D$ or HP $\beta C D$ markedly increases the solubility of indomethacin, an arylacetic derivative, at $\mathrm{pH}$ 6; enhancements of 15- and 6-fold, respectively, were detected with respect to the corresponding binary complexes. These systems also led to better in vitro release in a simulated gastric environment [57].

Several therapeutic drug families include acid groups in their structures, such as carboxylic acid, phenol and sulfonamide. For example, nonsteroidal anti-inflammatory agents such as flurbiprofen and diclofenac; diuretics that are carbonic anhydrase inhibitors, such as furosemide and acetazolamide, which is also used for the treatment of glaucoma, among other pathologies; and antibacterials such as sulfisoxazole and norfloxacin. Almost all exhibit several disadvantages, including low aqueous solubility, limited bioavailability and chemical instability [10], which often makes it difficult to fully take advantage of their therapeutic properties. In particular, for drugs belonging to these categories, for which rapid onset of therapeutic action is required, such as analgesics, and whose absorption is not hampered by poor permeability through membranes, poor solubility or slow dissolution could delay the desired effects. In addition, slow dissolution of anti-inflammatories can also increase local side effects associated with medications (e.g., gastric irritation) [58]. Sulfisoxazole is a weak acidic antibacterial that, like many sulphonamides, exhibits poor aqueous solubility, offering difficulties in pharmaceutical formulation. To overcome this drawback, a promising alternative is complex formation with CDs, which may allow an increase in the aqueous solubility of sulfisoxazole. However, if the complexation efficiency is not very high, relatively large amounts of CDs must be used to complex small amounts of the drug, in order to achieve the required solubility increase. Granero et al. demonstrated that the aqueous solubility of sulfisoxazole was significantly improved by the formation of multicomponent complexes with $\mathrm{HP} \beta C D$ and a basic substance such as triethanolamine (TEA) [59]. In addition, the sulfisoxazole-TEA-HP $\beta C D$ complexes have been studied both in solution by phase-solubility analysis and in solid state using differential scanning calorimetry (DSC), thermogravimetric analysis (TA), infrared spectroscopy (IR) and dissolution assays. The authors observed that the dissolution profiles of the lyophilized inclusion complexes showed faster dissolution rates compared than the prepared physical mixtures and the pure drug; however, the improvement was better with the ternary system.

Taking into account that nonsteroidal anti-inflammatories exhibit slight water solubility, some authors have suggested their inclusion in $\mathrm{CD}$ complexes to revert this problem. Accordingly, ternary CD complexes with ethanolamines were obtained by Maitre et al. [60] to improve the solubility of flurbiprofen, since it is one of the most potent inhibitors of platelet aggregation currently available. However, because flurbiprofen is conventionally administered orally, it causes a number of gastrointestinal disorders that become an issue in terms of side effects. For this reason, and taking into account that some researchers have studied the effects of CDs on transdermal permeation, these authors developed a system that allowed not only an increase in the solubility of flurbiprofen, but also application 
of the drug through the skin. Since the efficiency of complexation is not frequently very high, it can be improved through the use of a proper third component. In addition, they also found that the formation of salts with monoethanolamine (MEA) or diethanolamine (DEA) improved the percutaneous absorption of piroxicam, another anti-inflammatory drug [61]. Considering the above concepts, for another study the authors decided to use the hydroxypropyl derivative of $\beta C D, H P \beta C D$, due to its higher aqueous solubility, and three ethanolamines (Figure 6) (MEA, DEA and TEA). In addition, they highlighted that as of the time of publication, no studies had been reported that addressed the influence of joining CD complexes of lipophilic drugs with ethanolamines, thereby simultaneously exploiting $\mathrm{CD}$ and ethanolamines' solubilizing power to improve the dermal absorption, favoring delivery through the skin. Solubility studies of flurbiprofen and each alkanolamine showed that TEA and DEA were effective at improving the solubility through a synergistic effect. On the contrary, ternary systems with MEA and HP $\beta C D$ did not show a positive effect. The solid complexes, prepared through the freeze-drying method, were characterized by IR, DSC and TA. From the results provided by these studies, the salt formation of flurbiprofen was corroborated by interactions with alkanolamines and complexation with HP $\beta C D$. In dissolution studies, it was found that a strong increase in the dissolution profile could be observed with the ternary systems, compared with the pure drug and the binary complexes. Flurbiprofen-HP $\beta C D-M E A$ showed the best profile. In view of the results obtained in the first stage of this work, the authors studied the effect that complexation with MEA and $\mathrm{HP} \beta C D$ could have with the addition of binary cosolvent mixtures that are enhancers of the permeation, such as isopropyl myristate/ethanol and isopropyl myristate/propylene glycol, on the solubility of flurbiprofen. The mixing of HP $\beta C D$ with the binary cosolvent systems, consisting of isopropyl myristate and propylene glycol, significantly enhanced the skin permeation for the flurbiprofen-MEA complex after $12 \mathrm{~h}$ of application. This combination gave the best permeation profile for this complex among all the formulations tested. In this system, $\mathrm{HP} \beta C D$ appears to exert a cooperative effect toward enhancing the drug complex's permeation.

(A)

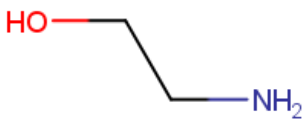

(B)<smiles>OCCNCCO</smiles>

(C)

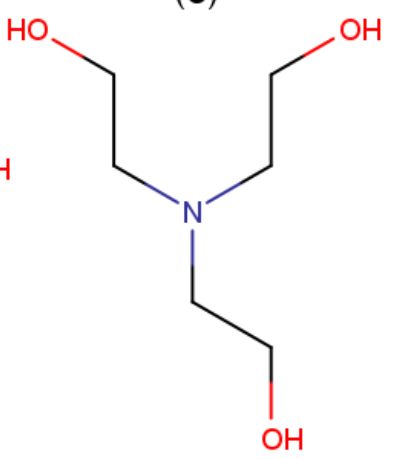

Figure 6. Molecular structures of: (A) monoethanolamine, (B) diethanolamine and (C) triethanolamine.

Garnero and Longhi [62] have studied the interactions of ascorbic acid with HP $\beta C D$ and TEA, separately and in combination. The first objective established for this work was to verify the interactions that could exist among ascorbic acid, HP $\beta C D$ and TEA. For these investigations, physicochemical methods such as DSC, FTIR, ${ }^{1} \mathrm{H}$ NMR and ${ }^{13} \mathrm{C}$ NMR spectroscopies were used to analyze the binary and multicomponent complexes and physical mixtures. In addition to the above, the authors investigated the formation of $\mathrm{HP} \beta C D$ aggregates, and whether the systems obtained improved the stability of ascorbic acid in solution, though which the values of the stability constants of the complexes and the degradation rates of ascorbic acid were obtained from degradation studies. Comparisons of the results obtained by DSC and FTIR of the systems prepared by freeze-drying with those obtained by physical mixing confirmed interactions between the components. The changes 
observed in the DSC thermograms and in the IR spectra are undoubtedly clear evidence of interactions between ascorbic acid and the other two compounds, suggesting the formation of a complex. By the NMR studies, it was possible to propose the formation of an association complex between ascorbic acid and TEA, which then formed a ternary system through interactions with the hydroxyl groups on the external surface of the $\mathrm{CD}$. The evidence on the formation of aggregates was obtained from the changes experienced in the chemical shifts of the protons towards high fields, from the graphs produced for the pure HP $\beta C D$ solution, the $\mathrm{HP} \beta C D$ solution containing ascorbic acid and the HP $\beta C D$ solution containing ascorbic acid and TEA, as a function of the inverse of the total concentration of HP $\beta C D$. Through these findings, it was proposed that the formation of aggregates of $\mathrm{HP} \beta C D$ is promoted by ascorbic acid. As ascorbic acid degrades rapidly in aqueous solutions, its effects on stability when complexed with HP $\beta C D$ and TEA, either separately or in combination, were studied by obtaining graphs of the observed rate constants as a function of the ligand concentration. The conclusions of these studies were that there is an increase in the stability of ascorbic acid after the addition of TEA, and that the multicomponent complex causes even greater stabilization than $\mathrm{HP} \beta C D$ alone. In addition, an approximately 17 -fold increase in the stability of ascorbic acid was evidenced in the presence of both ligands in an aqueous solution.

Acetazolamide, a drug used orally to lower intraocular pressure in glaucoma patients, is a diuretic and a carbonic anhydrase inhibitor. Large doses of the drug must be used to obtain the desired reduction in intraocular pressure, which usually produces systemic side effects, the most frequent being diuresis and metabolic acidosis. Therefore, topical administration of acetazolamide is preferred over systemic administration. The two major problems that hinder the topical effectiveness of acetazolamide are its poor aqueous solubility and its low corneal permeability. Therefore, taking into account the positive results previously obtained with sulfisoxazole, Granero et al. [63] decided to prepare ternary inclusion compounds of acetazolamide, HP $\beta C D$ and TEA, intended for topical ocular administration. A significant increase in the solubilizing power of HP $\beta C D$ was obtained by the simultaneous complexation and salt formation with TEA. The scarcely water-soluble acetazolamide, when forming a ternary system of drug-HP $\beta$ CD-TEA, is more available in aqueous $\mathrm{HP} \beta C D$ solutions, which should make the complex more effective for drug delivery to the cornea's surface. Furthermore, the top results in release studies with formulations containing HP $\beta C D$ and TEA highlighted TEA as an effective additive for the corneal transport of acetazolamide in aqueous eye drops. In addition, the $\mathrm{pH}$ of the formulation containing the ternary complex was within physiological $\mathrm{pH}$ values. The ternary complexes prepared by the freeze-drying method were analyzed by means of IR, and according to the changes in the spectra, it was suggested that the carbonamido group of the drug is involved in the inclusion process, which is reflected by the shifts in the $\mathrm{C}=\mathrm{O}$ vibrational peak. The in vitro release studies of acetazolamide for all the formulations were carried out using the membrane diffusion technique. They indicated that acetazolamide-HP $\beta$ CD-TEA was significantly better than the others. When comparing the release data of acetazolamide in pure water with those of the binary inclusion complex and its corresponding physical mixture with acetazolamide and HP $\beta C D$, it is clear that the acetazolamide release was faster from formulations containing the binary systems with HP $\beta C D$. Besides, the drug release from the inclusion complex was more complete than that of its corresponding physical mixture. It was found that the results of the in vitro release studies were in agreement with those obtained from the solubility ones, in which the ternary complex acetazolamideHP $\beta C D-T E A$ showed the highest drug solubility. Perhaps the difference in release rate could be attributed to the changes in solubility shown by the different formulations of acetazolamide. Furthermore, significantly better results with formulations containing $\mathrm{HP} \beta C D$ and TEA in the release studies established TEA as an effective additive for the corneal transport of ACZ in aqueous eye drops. Since the eye tolerates a narrow range of $\mathrm{pH}$, it is important to note that formulations of binary and ternary inclusion complexes of acetazolamide with HP $\beta C D$ and/or TEA maintain the $\mathrm{pH}$ within the physiological 
$\mathrm{pH}$ range of 6.2-8.4, thereby respecting the $\mathrm{pH}$ range tolerated by the eye. In addition, both binary and ternary acetazolamide systems with HP $\beta C D$ and TEA were shown to allow excellent drug stability over several days.

Due to the good results obtained in the previous study, the authors decided to continue with the investigations regarding acetazolamide complexes with $\mathrm{HP} \beta C D$ alone or with TEA by studying crystalline properties, dissolution and the effect on intraocular pressure [64]. They found that the preparation conditions could vary the crystal structure of acetazolamide powder. The particle morphology and the polymorphic form were changed after freeze-drying, whereby the starting acetazolamide was converted to pure form A. The solid products obtained by freeze-drying, and the physical mixtures prepared for comparative purposes using an agate mortar, were characterized by DSC, TA, X-ray powder diffraction (XRPD), scanning electron microscopy (SEM) and FTIR, and the obtained results suggested the formation of inclusion complexes of acetazolamide with HP $\beta C D$ alone or with TEA, by the freeze-drying method, and the conversion of the drug into the amorphous state. In addition, binary and ternary systems of acetazolamide obtained by freeze-drying exhibited satisfactory acetazolamide dissolution rates. The effects of the drug and its complexes with HP $\beta C D$ alone or with TEA regarding the drop in the intraocular pressure (IOP) in normotensive rabbits were investigated. With these binary and ternary lyophilized acetazolamide systems, the maximum IOP-lowering effect obtained with these binary and ternary lyophilized acetazolamide systems occurred at around $90 \mathrm{~min}$, whereas a longer maximum IOP-lowering effect was shown by the ternary complex acetazolamide-TEA$\mathrm{HP} \beta C D$ than the binary system. These results agree with those obtained in dissolution studies, in which the ternary system showed longer dissolution times in relation to the lyophilized binary one. Considering that large oral doses of acetazolamide lower IOP, but usually lead to a multitude of systemic side effects, including gastrointestinal upset, researchers [65] decided to evaluate the effect of acetazolamide on the histological structure of rat duodenal mucosa. They studied the protective effect that the acetazolamide-HP $\beta C D$ complex could exert, with and without the addition of a third compound, on the gut epithelial layer, through histological and ultrastructural examinations of sections of rat duodenum exposed to acetazolamide or its formulations. Furthermore, the passage of acetazolamide and its binary or ternary complexes through the duodenal mucosa was analyzed using the single-pass intestinal perfusion method in rats. It was determined that acetazolamide modifies intestinal permeability and injures the small intestine of the rat, and that acetazolamide complexes significantly mitigate the damage caused by the drug on the mucosa, which was proven by microscopic studies. In addition, it was found that the ternary complexes of acetazolamide with $\mathrm{HP} \beta C D$ in combination with TEA or calcium ions markedly improved the apparent permeability of acetazolamide through the duodenal epithelium, alongside the additional property of maintaining the integrity of the intestinal epithelium after drug administration. These excellent results of ternary acetazolamide systems with $\mathrm{HP} \beta C D$, in the presence of TEA or calcium ions, can be attributed to the rapid release of acetazolamide into the underlying epithelium, thereby enhancing the amount of drug available for absorption. The authors also postulated that the obtaining of ionic pairs competes with the complex formation and could shift the equilibrium towards the dissociation of the complex, decreasing its stability.

Like flurbiprofen, diclofenac is also characterized by low aqueous solubility, poor dissolution and gastrolesive actions, whereby the complexation with $\mathrm{M} \beta C D$ and MEA was investigated in order to determine if this system alleviates these undesirable effects. Its influence on the percutaneous absorption of diclofenac is being studied [66]. Transdermal delivery of diclofenac would be advantageous, since it would avoid hepatic first-pass metabolism and considerable gastrointestinal disturbances. In solution the complexes were studied by phase-solubility analysis and ${ }^{1} \mathrm{H}$ NMR spectroscopy, and these results indicate that 1:1 inclusion stoichiometry was present, and the ${ }^{2}$ D ROESY NMR experiment showed that in the inclusion complex of diclofenac and $\mathrm{M} \beta C D$, the dichlorophenyl part of the drug was included in the $\mathrm{M} \beta \mathrm{CD}$ cavity. Moreover, the solid complex was prepared by the 
freeze-drying method and analyzed using DSC and TA. These studies allowed obtaining more information on possible drug-ethanolamine solid-state interactions. The facts observed in the thermograms, such as disappearance, shifting, decreasing or widening of the peaks, could be indicating a complexation of the diclofenac-MEA salt into the cavity of $\mathrm{M} \beta C \mathrm{CD}$. In addition to the above, the cumulative permeation of diclofenac from different formulations through human skin was investigated, and it could be determined that a drug permeation enhancement of 67 -fold was obtained at $30 \mathrm{~h}$, with the ternary diclofenac$\mathrm{M} \beta C D-M E A$ complex. This good result was attributed to the fact that MEA prevents complexation, allowing greater availability of the free drug, and thus promoting the skin absorption of diclofenac.

Benznidazole, a drug mainly used to treat Chagas disease, is classified as class II in the BCS due to its low solubility and high rate of penetration through biological barriers. Due to these properties, it would be beneficial to increase the solubility of the drug through the use of technological alternatives, which increase its efficacy. Due to this, Nunez de Melo et al. [67] selected complexation with $\beta C D$ for this purpose, among the various techniques available to improve the solubility of nonpolar drugs in aqueous vehicles. Multicomponent complexes of benznidazole and $\beta C D$ were prepared in the presence of hydrophilic polymer and TEA. By phase solubility-diagrams, in the systems with alkanolamine at different $\mathrm{pH}$ values, the occurrence of soluble complexes with 1:1 stoichiometry was determined, but the solubility in the ternary system was lower than that obtained for the binary with $\beta C D$, with which it was possible to increase by 2 -fold the solubility of the pure drug. The authors attribute this fact to a co-solvency effect or competition for the cavity of $\beta C D$. Through molecular dynamic simulations, it was shown that TEA acts by hindering the formation of the benznidazole- $\beta C D$ complex in accordance with the experimental results, which showed lower solubility of benznidazole due to such competitive phenomena. In addition, through the ${ }^{1} \mathrm{H}$ NMR studies they carried out, it was found that all benznidazole protons have greater protective effects with the addition of TEA to the binary system with $\beta C D$, which implies a strong interaction between benznidazole and TEA, thereby confirming the co-solvency effect.

In another study, the same group [68] published the preparation of spray-dried complexes of benznidazole with $\beta C D$ and TEA, which were carefully controlled using FTIR, XRPD and SEM images. The results obtained allowed verifying the obtaining of systems that involve the three components, but on the other hand, the presence of the TEA did not significantly change the benznidazole dissolution, compared with the binary complex. In previous scientific works, it was possible to verify the synergistic effect that $\beta C D$ and TEA exert on molecules that are not very soluble in water and are acidic, which does not seem to happen for benznidazole, due to its neutral nature and non-ionization capacity. In contrast, TEA appears to disturb the insertion of benznidazole into the hydrophobic cavity of $\beta C D$, which may explain the failure of TEA to increase the aqueous solubility of benznidazole: $\beta C D$.

Methotrexate is an anticancer drug that is also used to treat "psoriasis," which is a chronic inflammatory disease that causes skin lesions. However, due to its short halflife (1.5 to $3.5 \mathrm{~h}$ ), frequent administration of high doses of the drug is required, which is associated with the appearance of side effects. Therefore, an alternative to increase the effectiveness of methotrexate for the treatment of psoriasis would be its application directly to the lesions with the consequent permeation of the drug through the skin, which would restrict the possible undesirable effects. Nevertheless, the topical application of methotrexate has certain limitations. Due to this, Barbosa et al. [69] aimed to develop nanotechnological drug delivery systems based on $C D$ in an attempt to solve the drawbacks exhibited by this drug permeation. The selected strategy was to obtain ternary complexes of $\beta C D$ with TEA, taking into account the capacity of alkanolamine to enhance the inclusion of the host drugs by $\mathrm{CD}$. Additionally, especially in relation to ternary complexes for topical application, TEA proved to be an efficient complement with which to enhance the corneal release of acetazolamide, thereby improving the in vivo efficacy of the drug 
and decreasing its unwished consequences. The correlations in an aqueous medium were investigated by molecular modeling, phase solubility diagrams and NMR studies. The solid systems were prepared by the freeze-drying method, and were characterized using SEM, IR, DSC, TA, C,N,H elementary analysis, XRPD and in vitro drug dissolution studies. The linear phase diagram obtained suggested the production of soluble complexes with 1:1 stoichiometry. The maximum $\beta C D$ concentration studied increased the apparent methotrexate aqueous solubility about 15 -fold. Besides, with the addition of TEA to the binary samples, a synergistic effect was observed, with increments in the drug solubility of 30 -fold. In the ${ }^{1} \mathrm{H}$ NMR studies, the ROESY spectrum obtained for binary and ternary complexes showed interactions between the aromatic protons of methotrexate and the protons of the internal cavity of $\beta-\mathrm{CD}$, indicating that the alicyclic aromatic ring of the drug is deeply inserted in the CD cavity, in both binary and multicomponent complexes. In the molecular modeling study, it was shown that TEA significantly increased the affinity of methotrexate for $\beta-C D$ through an electrostatic interaction that was not observed for the binary complex. Unlike in other studies, TEA did not compete with the CD cavity, but it stabilized the methotrexate- $\beta C D$ interaction. For methotrexate- $\beta C D-T E A$ freezedried complexes, the IR results proved that the drug-CD interactions identified by NMR studies remained in solid phase. Thermal and structural studies also pointed out this fact, and highlighted the increase in thermal stability of the drug. The impacts of the ternary complex on the objectives were further confirmed by the results obtained in the in vitro dissolution studies. In vitro drug release studies that were performed for pure methotrexate and for binary and ternary freeze-dried complexes with the objective of evaluating the effect of complexation on the drug dissolution rate revealed much faster dissolution by the drug in both in binary and ternary freeze-dried complexes. The dissolution performance of the ternary complex was the fastest, demonstrating the success of the lyophilized ternary complex.

\section{Water-Soluble Polymers as Auxiliary Agents}

Water-soluble polymers are known to interact with the outer surfaces of $\mathrm{CD}$ and drug-CD complexes, forming aggregates or co-complexes that show values of stability constants constant higher than those of binary drug-CD systems [70]. They play a role in stabilization, preventing aggregations of complexes and several types of particulate in pharmaceutical systems. They can also increase the solubility of complexes and decrease $\mathrm{CD}$ mobility by changing the hydration properties of CD molecules [71]. In this review, the use of different water-soluble polymers as third components in multicomponent $\mathrm{CD}$ complexes is analyzed.

\subsection{Polyvinylpyrrolidone}

Polyvinylpyrrolidone (PVP) can be used as an aqueous solution or a powder that can be dissolved in various organic solvents and water. It has excellent physiological compatibility, complexing ability, film-forming capability and hygroscopic capacity. PVP can be used in cosmetics as a viscosity-enhancing agent, a film agent, an adhesive and a lubricant. In the pharmaceutical field, PVP-K30 (Figure 7A) is an excellent excipient used as a dissolution assistant for injections, a binder for tablets, a dispersant for liquids, a flow assistant for capsules, a stabilizer for enzymes and heat sensitive drugs, an antitoxic element and lubricator for eye drugs and a coprecipitant for poorly soluble drugs [72]. Efavirenz is the most widely used drug for the antiretroviral treatment of acquired immunodeficiency syndrome. However, it has low solubility and it does not exhibit appropriate bioavailability. It is classified according to the BCS as a class II drug, with high permeability but low aqueous solubility $(\sim 3-9 \mu \mathrm{g} / \mathrm{mL})$ [73], which interferes with its therapeutic action. Among several drug delivery systems, the multicomponent systems with low-concentration CDs and hydrophilic polymers are the most promising alternatives for increasing the aqueous solubility of drugs $[74,75]$. Efavirenz-M $\beta C D-P V P-K 30$ with $1 \%$ PVP-K30 promoted the best increase in the solubility and delivery of efavirenz, when the dissolution profiles were 
analyzed. More than $80 \%$ of the total efavirenz was delivered in $30 \mathrm{~min}$, compared with less than $25 \%$ by efavirenz alone. That is, the PVP-K30 represented a co-complexing agent that increased the hydrophilic potential of $\mathrm{M} \beta \mathrm{CD}[67,76]$. The use of the kneading method to obtain the multicomponent solid-state system permitted the formation of a non-crystalline, uniform particle, which increased the dissolution rate of the drug, and provided an increase in the stability of the drug, as demonstrated by thermal analysis. DSC analysis suggested that the presence of M $\beta C D$ and PVPK-30 delays the efavirenz melting process, leading to both a change in its peak temperature and widening of the peak, with a consequent increase in the energy involved. Consequently, it is suggested that the system gives stability to efavirenz. Moreover, TA showed that the kneaded product loses less mass, demonstrating that the product obtained by kneading is more stable [75] due to strong electrostatic interactions between PVP-K30 and M $\beta C D$, as shown in the IR spectrum.

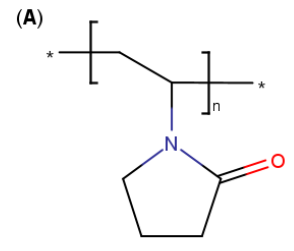

(C)

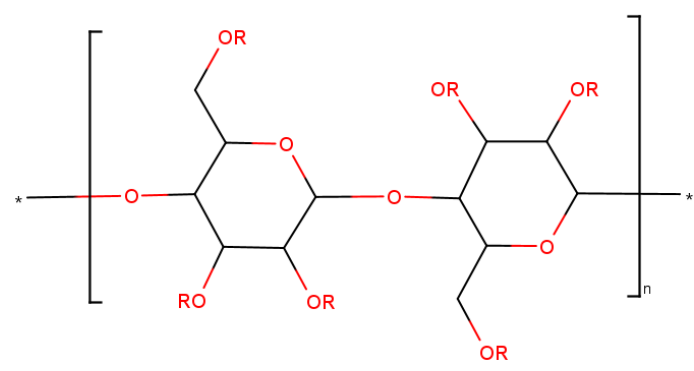

$\mathrm{R}=-\mathrm{H},-\mathrm{CH}_{3}$ or $-\mathrm{CH}_{2}-\mathrm{CHOH}-\mathrm{CH}_{3}$

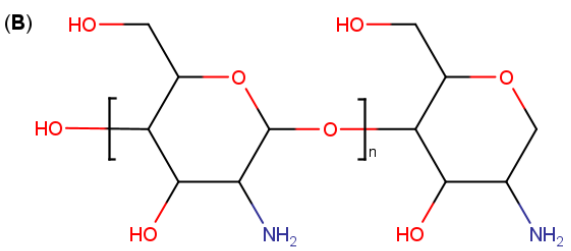

(D)<smiles>COC1OC(C(=O)O)C(OC2OC(CO)C(O)C(OC)C2NC(C)=O)C(O)C1O</smiles>

(E)<smiles>CC(C)(O)CCOC(C)(C)C</smiles>

(F)<smiles>[Y]C(C)(O)COC(C)CC(C)OC(C)(C)COC(C)C</smiles>

Figure 7. Molecular structures of (A) PVP-K30, (B) chitosan, (C) hydroxypropylmethylcellulose, (D) hyaluronic acid, (E) polyethylene glycol and (F) poloxamer.

PVP-K30 was also used in a multicomponent complex with $\beta C D$ and cefuroxime axetil, to improve the latter's pharmaceutical characteristics, via the kneading method [77]. Cefuroxime axetil is a prodrug of cefuroxime cephalosporin, which is used for pharyngitis, respiratory tract infections, acute bacterial otitis, simple skin infections and urinary tract infections. It is a BCS class II drug, so it has less aqueous solubility with an oral bioavailability of $37 \%$ on an empty stomach, which increases to $52 \%$ if taken after meals. In this multicomponent complex of cefuroxime axetil with $\beta C D, P V P-K 30$ can act as a ternary component to improve its pharmaceutical characteristics. The multicomponent complex leads to a better dissolution profile than the $\beta C D$-cefuroxime axetil complex: $>85 \%$ cefuroxime axetil release within $30 \mathrm{~min}$. This release is much more effective due to the hydrophilic nature of PVP-K30, which radically improves the phase solubility parameters, such as stability constant and complexation efficiency, while interacting simultaneously with cefuroxime axetil through electrostatic interactions and salt formation, and $\beta C D$ via H-bonding. The in vitro taste-masking study also revealed that the multicomponent 
complex was able to mask the bitter taste of the cefuroxime axetil [78]. Cefuroxime axetil's physicochemical characteristics were also improved via the dual mechanism of HP $\beta C D$ complexation in the presence of a water-soluble polymer and simultaneous particle size reduction using spray-drying technology [78]. The polymers are believed to enhance the stability constants of drug-CD complexes, the interactions with drug-CD complexes and the interactions with the outer surfaces of CDs [79]. The addition of water-soluble polymers supplies an advantage through the complexation efficiency of HP $\beta C D$ by establishing molecular interactions based on the solubilization of the amorphous form of cefuroxime axetil, such as Van der Waals dispersion forces, hydrophobic bonds or hydrogen bonds in the presence of PVP [80]. The particle size revealed that the binary and multicomponent complexes were micro-sized. This led to a rise in the specific surface area, and therefore, to faster dissolution for cefuroxime axetil particles. Therefore, an increase in bioavailability would be expected.

Solid-state ibuprofen manipulation continues to be a challenge for researchers because of its low glass transition temperature and its tendency to recrystallize at room temperature. For this reason, the formation of a water-soluble and stable multicomponent system ibuprofen- $\beta C D-P V P-K 30$ in a solid state was evaluated, in order to simultaneously improve the physical stability and the dissolution of ibuprofen [81]. This system was obtained through the milling technique, which represents an economic, eco-friendly and simple process. The milling technique has succeeded at improving the bioavailability and the solubility of numerous poorly water-soluble drugs. The formation of such a multicomponent system denotes a new alternative to improving the bioavailability and solubility of ibuprofen, which preserves its stability in an amorphous state. This system shows a substantial enhancement in dissolution rate compared with pure ibuprofen. After $0.5 \mathrm{~min}$, the amount of ibuprofen released by the multicomponent system was practically quadrupled compared to the drug alone and the binary systems ibuprofen- $\beta C D$ and ibuprofen-PVPK30. In this system, PVP-K30 may partially or totally coat the ibuprofen- $\beta C D$ complex, leading to the formation of a stable and water-soluble amorphous system. The physical stability of amorphous ibuprofen (at RH: $75 \% / \mathrm{T}=40{ }^{\circ} \mathrm{C}$ for 6 months) can be achieved by forming a multicomponent system in the ratio 1:1:0.5 $w / w$ obtained by milling the drug into solid state at $25^{\circ} \mathrm{C}$. IR and NMR spectroscopies have suggested the presence of electrostatic interactions and intermolecular $\mathrm{H}$-bonds between ibuprofen molecules and carriers. XRD, ${ }^{1} \mathrm{H}-\mathrm{NMR}$ shifts and SEM results have clearly revealed the formation of amorphous complexes coated by PVP-K30 films. This represents an advantage in terms of ibuprofen release in comparison with ibuprofen- $\beta C D$ and ibuprofen-PVP-K30 in a 1:1 $w / w$ ratio [82].

\subsection{Chitosan}

Chitosan (CH) (Figure 7B) is a biopolymer of aminopolysaccharides composed of randomly distributed units of $\beta$-(1-4) D-glucosamine (deacetylated units) and $N$-acetylD-glucosamine (acetylated unit). CH is a biocompatible, antibacterial and environmentally friendly polyelectrolyte with a variety of applications, including water treatment, chromatography, additives for cosmetics, biodegradable films, biomedical devices and microcapsule implants for controlled release in drug delivery [83]. $\mathrm{CH}$ has been widely reported for its ability to increase the permeability of drugs [84] and for its availability as a carrier system for drug targeting [85]. Trimethyl chitosan (TMC) is a derivative of $\mathrm{CH}$ especially known for its abilities to increase drug bioadhesiveness and biocompatibility [86], and permeation and bioavailability through the intestinal mucosa [87]. In the case of modafinil, the complexation efficiency obtained by the use of TMC is better compared with the binary system from the manufacturing point of view because TMC can be produced via easier product manufacturing compared with the complex containing $\mathrm{CD}$ alone. The aggregation of $\mathrm{CD}$ derivatives by TMC and the creation of a microenvironment with high solvation power could be the mechanism behind the ability of TMC to impact the modafinil solubility [88]. The phase solubility study and its correlation with the DSC study 
proposed that the high dissolution nature of the metastable polymorphic form, which has not been converted into a stable but poorly soluble polymorphic crystalline [89] form, could be the reason for the solubility enhancement of TMC-mediated multicomponent modafinil complex. On the contrary, unmodified $\mathrm{CH}$-based multicomponent complex indicated absolute conversion of modafinil crystalline form to amorphous form during freeze-drying.

\subsection{Hydroxypropylmethylcellulose}

Hydroxypropylmethylcellulose (HPMC) (Figure 7C) is a water-soluble semisynthetic derivative of cellulose substituted with methoxy and hydroxypropyl groups [90]. Diosmin, a drug with poor water-solubility which limits its therapeutic applicability, possesses strong antioxidant activity, along with other interesting effects, including anti-inflammatory, anticancer and anti-ulcer activities [91]. Therefore, binary and multicomponent complexes with CD and CD plus HPMC or PEG were assayed by Anwer et al. [92]. The stability constants determined for the diosmin- $\beta C D$ system and diosmin- $\beta C D-H P M C$ system were 151 and $186 \mathrm{M}^{-1}$, respectively, suggesting relatively strong interactions between $\beta C D$ and the diosmin. These interactions were established through intermolecular forces between the $\beta C D$ cavity and diosmin, resulting in the inclusion of diosmin within the $\beta C D$ cavity. A significant rise in solubility was achieved through the addition of $1 \% w / w$ of HPMC in the presence of $\beta C D$.

Norfloxacin is a poorly soluble drug, classified as a BCS class IV agent. The effect of HPMC and $\beta C D$ on norfloxacin was investigated by the solvent evaporation method to prepare the inclusion complex. Through phase solubility studies, the stability constant value was increased from $103.49 \mathrm{M}^{-1}$ for $\beta-C D$ to 253.34 or $307.49 \mathrm{M}^{-1}$ when $2.5 \%(w / v)$ or $5 \%(w / v)$ of HPMC were added. These values showed the formation of a multicomponent complex comparatively more stable than the binary one. The complexation with $\beta C D$ significantly enhanced the dissolution rate of norfloxacin in comparison with pure norfloxacin. However, HPMC did not show a significant increase in norfloxacin release [93].

\subsection{Hyaluronic Acid}

Celecoxib is a nonsteroidal anti-inflammatory drug that has inhibitory effects on vascular endothelial growth factor, as it demonstrated in numerous anticancer studies with diverse cell types through the inhibition of the COX-2 enzyme, and it has anti-proliferative and anti-angiogenic effects on several cell types, including endothelial cells [94,95]. It is used in macular degeneration and diabetic retinopathy. However, the oral dose required to obtain a therapeutic effect is very high, which results in cardiovascular problems and adverse effects [96]. Intravitreal injections can offer a high concentration of celecoxib to the retina, but can potentially produce retinal toxicity. Moreover, recurrent intravitreal injections have been associated with complications such as endophthalmitis and retinal detachment [97]. Consequently, there is a need to develop non-invasive methods for effective retinal drug delivery. As stated above, Jansook et al. [98] developed binary and multicomponent complexes of celecoxib (containing RM $\beta C D$ and $\gamma C D$ as solubilizers, and HPMC and hyaluronic acid-HA, Figure 7D, as mucoadhesive polymers) to try to optimize these unfavorable properties. HA is a non-sulphated glycosaminoglycan and is composed of repetitions of polymeric disaccharides of D-glucuronic acid and $N$-acetyl-D-glucosamine linked by glucuronidic $\beta$ (1-3) bonds. It forms specific and stable tertiary structures in aqueous solutions [99]. Celecoxib-CD suspensions with $0.5 \% w / v$ HA or HPMC provide good mucoadhesive properties that were believed to be able to raise celecoxib's residence time, resulting in enhanced ocular drug bioavailability. Different systems were assayed, and the microsuspension eye drops with multicomponent complex celecoxib-RM $\beta C D-H A$ aggregates exhibited relatively good mucoadhesion; provided the maximum drug flux through the simulated vitreous humor, through the semipermeable membrane and through scleral tissues; and had cytocompatibility with the human retinal pigment epithelial (RPE) cell line [98]. 


\subsection{Polyethylene Glycol}

Polyethylene glycol (PEG) (Figure 7E) is chemically a petroleum-based polyether that is much used in medicine and industrial manufacturing. PEG is also called polyethylene oxide or polyoxyethylene, according to its molecular weight. PEG's structure is generally expressed as $\mathrm{H}-\left(\mathrm{O}-\mathrm{CH}_{2}-\mathrm{CH}_{2}\right) \mathrm{n}-\mathrm{OH}$. For example, diosmine complexation with PEG 6000 increased the stability constant value from $151 \mathrm{M}^{-1}$ for the binary complex to $236 \mathrm{M}^{-1}$ for the diosmine- $\beta C D-P E G 6000$ system. This showed that a significant increase in solubility was reached by the addition of $1 \% w / w$ of PEG 6000 in the company of $\beta C D$. According to dissolution studies, the dissolution of diosmine was found to be $14 \%$ or $21 \%$ at $\mathrm{pH} 1.2$ or 7.4 after $60 \mathrm{~min}$, respectively. Release of kneaded diosmine- $\beta C D$ complex was increased to $29 \%$ (2-fold) and $56 \%$ (2.6-fold) at pHs 1.2 and 7.4, respectively. However, significant rises in dissolution of $35 \%$ (2.4-fold) at $\mathrm{pH} 1.2$ and $73 \%$ (3.4 fold) at $\mathrm{pH} 7.4$ were observed for the diosmine- $\beta C D-P E G 6000$ complex, which may be attributed to the amorphous nature of the solid that was confirmed by XRPD studies. Moreover, this increase in solubility produced the highest radical scavenging activity $(75 \%$ at $100 \mu \mathrm{g} / \mathrm{mL})$ for the diosmine- $\beta$ CD-PEG 6000 complex [92].

\subsection{Poloxamer}

Poloxamer $(\mathrm{P})$ is a non-ionic polymer, a block copolymer made of poly(oxy ethylene) and poly(oxy propylene) (Figure 7F). Some previous works have shown that the addition of $\mathrm{P}$ to $\mathrm{CD}$ leads to the formation of drug nanocarriers and colloidal particle systems [100]. The drug's incorporation into P micelles can improve chemical stability and drug solubility [101] and also regulate the cell accumulation acting on efflux pumps and biodistribution [102].

One of the main components of the Centella asiatica is asiaticoside, which has become interesting today for its wound healing mechanism. Asiaticoside was found to significantly improve the rate of wound healing and enhance the tensile strength of wound tissues [103]. Due to its poor aqueous solubility, permeation through the biological membranes is difficult, leading to low bioavailability. Interestingly, the additive effect of SBE $\beta C D$ solubilization of asiaticoside was observed with P407. The enhancement of solubilization with the addition of P407 to asiaticoside-SBE $\beta C D$ was approximately $12 \%$. This is high enough to allow less SBE $\beta C D$ to be used in the final formulation. In addition, a slight dissolution retardant effect was observed for the asiaticoside-SBE $\beta C D-P 407$ complex. When the multicomponent complexes came into contact with the dissolution medium, the polymers swelled and formed a hydrophilic layer, resulting in a slow diffusion rate for the drug. However, asiaticoside's release rate from asiaticoside-SBE $\beta C D-P 407$ was increased up to $93 \%$ in $120 \mathrm{~min}$. The stability constant of the asiaticoside-SBE $\beta C D$ complex was slightly higher than that of the multicomponent complex. There was only a slight enhancement of dissolution efficiency at $120 \mathrm{~min}$ for the multicomponent complex. This successful dissolution rate might be due to the decrease in crystallinity of the asiaticoside during the freeze-drying process [104].

$\beta$-lapachone is a 1,2-orthonaphthoquinone derived from the woof of the lapacho tree. $\beta$-lapachone provoked cell death in human cancer cells [105] through a mechanism that requested the presence of the NAD $(\mathrm{P}) \mathrm{H}$-quinone oxidoreductase- 1 . $\beta$-lapachone administration increases the generation of reactive oxygen species in cells or tissues with the presence of NQO1, causing extensive DNA damage. Moreover, $\beta$-lapachone causes losses of NAD+ and ATP pools, which then inhibits DNA repair and accelerates cell death [106]. NQO1 is overexpressed in breast tumors with respect to normal adjacent tissue, which makes $\beta$-lapachone a potential selective anti-tumoral drug for breast cancer [107]. However, the low aqueous solubility $(0.038 \mathrm{mg} / \mathrm{mL})$ and unspecific distribution of $\beta$-lapachone limit its use in clinical assays [108]. Seoane et al. [109] prepared a multicomponent system of $\beta$-lapachone in an optimal random $\mathrm{M} \beta \mathrm{CD}$-poloxamer 407 mixture. Then, its anti-tumor effects on proliferation, apoptosis, cell cycle, tumor growth and DNA damage were evaluated in vitro and in vivo using MCF-7 cells, human breast adenocarcinoma cells and immunod- 
eficient mice. This multicomponent system is fluid at room temperature, gels at over $29{ }^{\circ} \mathrm{C}$, and delivers a significant amount of $\beta$-lapachone, thereby facilitating intratumoral release, in situ gelation and the formation of a depot for time-release. When the $\beta$-lapachone multicomponent system was administered to MCF-7 cells, no changes in cell cycle were induced, despite producing increases in apoptosis and DNA damage. Additionally, intratumoral injection of the system into a mouse xenograft tumor model significantly decreased tumor volume while increasing apoptosis and DNA damage without evident toxicity to the liver or kidneys.

\section{Conclusions}

CDs are excipients widely used by the pharmaceutical industry that are incorporated in many pharmaceutical formulations marketed in several regions of the world. In recent decades, the development of multicomponent systems has increased the potential for CDs to not only to enhance drug solubility, dissolution and bioavailability, but to also allow the modulation of other drug properties, such as the stability and biological activity. The multicomponent complexes of $C D$ with organic acids or bases, amino acids and polymers have proven to be very useful for improving and controlling properties of ionizable, weakly ionizable and non-ionizable drugs. In general, the most suitable auxiliary agent and the most appropriate CD should be selected by considering the particular drug's physicochemical properties and the characteristics to optimize. For example, in the case of acidic drugs, the basic auxiliary agent TEA has been demonstrated to significantly enhance both the solubility and the permeability. Regarding using amino acids as auxiliary agents, arginine is the most used compound, since in general it shows a synergistic effect with the CD toward enhancing drug solubility. In summary, our analysis of the available literature showed the interest in multicomponent CD complexes as approaches with which to improve the therapeutic efficacy of drugs.

Author Contributions: V.A., C.G., M.R.L. and A.Z. contributed equally to this work. All authors have read and agreed to the published version of the manuscript.

Funding: This research received no external funding.

Institutional Review Board Statement: Not applicable.

Informed Consent Statement: Not applicable.

Data Availability Statement: Not applicable.

Conflicts of Interest: The authors declare no conflict of interest.

\section{References}

1. Morin-Crini, N.; Fourmentin, S.; Fenyvesi, É.; Lichtfouse, E.; Torri, G.; Fourmentin, M.; Crini, G. History of Cyclodextrins BT-The History of Cyclodextrins; Crini, G., Fourmentin, S., Lichtfouse, E., Eds.; Springer International Publishing: Cham, Switzerland, 2020; pp. 1-93; ISBN 978-3-030-49308-0.

2. Villiers, A. Sur la fermentation de la fécule par l'action du ferment butyrique. Compt. Rend. Acad. Sci. 1891, 112, 536-538.

3. Jambhekar, S.S.; Breen, P. Cyclodextrins in pharmaceutical formulations I: Structure and physicochemical properties, formation of complexes, and types of complex. Drug Discov. Today 2016, 21, 356-362. [CrossRef]

4. Morin-Crini, N.; Fourmentin, S.; Fenyvesi, É.; Lichtfouse, E.; Torri, G.; Fourmentin, M.; Crini, G. 130 years of cyclodextrin discovery for health, food, agriculture, and the industry: A review. Environ. Chem. Lett. 2021, 19, 2581-2617. [CrossRef]

5. Jansook, P.; Ogawa, N.; Loftsson, T. Cyclodextrins: Structure, physicochemical properties and pharmaceutical applications. Int. J. Pharm. 2018, 535, 272-284. [CrossRef] [PubMed]

6. Bom, A.; Bradley, M.; Cameron, K.; Clark, J.K.; Van Egmond, J.; Feilden, H.; MacLean, E.J.; Muir, A.W.; Palin, R.; Rees, D.C.; et al. A novel concept of reversing neuromuscular block: Chemical encapsulation of rocuronium bromide by a cyclodextrin-based synthetic host. Angew. Chem. Int. Ed. Engl. 2002, 41, 266-270. [CrossRef]

7. Conceição, J.; Adeoye, O.; Cabral-Marques, H.M.; Lobo, J.M.S. Cyclodextrins as excipients in tablet formulations. Drug Discov. Today 2018, 23, 1274-1284. [CrossRef] [PubMed]

8. Loftsson, T.; Brewster, M.E. Cyclodextrins as functional excipients: Methods to enhance complexation efficiency. J. Pharm. Sci. 2012, 101, 3019-3032. [CrossRef] 
9. Redenti, E.; Szente, L.; Szejtli, J. Drug/cyclodextrin/hydroxy acid multicomponent systems. Properties and pharmaceutical applications. J. Pharm. Sci. 2000, 89, 1-8. [CrossRef]

10. Redenti, E.; Szente, L.; Szejtli, J. Cyclodextrin complexes of salts of acidic drugs. Thermodynamic properties, structural features, and pharmaceutical applications. J. Pharm. Sci. 2001, 90, 979-986. [CrossRef] [PubMed]

11. Aiassa, V.; Zoppi, A.; Albesa, I.; Longhi, M.R. Inclusion complexes of chloramphenicol with $\beta$-cyclodextrin and aminoacids as a way to increase drug solubility and modulate ROS production. Carbohydr. Polym. 2015, 121, 320-327. [CrossRef]

12. Mura, P.; Maestrelli, F.; Cirri, M. Ternary systems of naproxen with hydroxypropyl- $\beta$-cyclodextrin and aminoacids. Int. J. Pharm. 2003, 260, 293-302. [CrossRef]

13. Mura, P.; Bettinetti, G.P.; Cirri, M.; Maestrelli, F.; Sorrenti, M.; Catenacci, L. Solid-state characterization and dissolution properties of Naproxen-Arginine-Hydroxypropyl- $\beta$-cyclodextrin ternary system. Eur. J. Pharm. Biopharm. 2005, 59, 99-106. [CrossRef]

14. Bramhane, D.M.; Saindane, N.S.; Vavia, P.R. Inclusion complexation of weakly acidic NSAID with $\beta$-cyclodextrin: Selection of arginine, an amino acid, as a novel ternary component. J. Incl. Phenom. Macrocycl. Chem. 2011, 69, 453-460. [CrossRef]

15. Mennini, N.; Maestrelli, F.; Cirri, M.; Mura, P. Analysis of physicochemical properties of ternary systems of oxaprozin with randomly methylated-ß-cyclodextrin and l-arginine aimed to improve the drug solubility. J. Pharm. Biomed. Anal. 2016, 129, 350-358. [CrossRef] [PubMed]

16. Sherje, A.P.; Patel, F.; Murahari, M.; Suvarna, V.; Patel, K. Study on effect of L-arginine on solubility and dissolution of Zaltoprofen: Preparation and characterization of binary and ternary cyclodextrin inclusion complexes. Chem. Phys. Lett. 2018, 694, 120-128. [CrossRef]

17. Sherje, A.P.; Kulkarni, V.; Murahari, M.; Nayak, U.Y.; Bhat, P.; Suvarna, V.; Dravyakar, B. Inclusion Complexation of Etodolac with Hydroxypropyl-beta-cyclodextrin and Auxiliary Agents: Formulation Characterization and Molecular Modeling Studies. Mol. Pharm. 2017, 14, 1231-1242. [CrossRef] [PubMed]

18. Suvarna, V.; Thorat, S.; Nayak, U.; Sherje, A.; Murahari, M. Host-guest interaction study of Efavirenz with hydroxypropyl- $\beta$ cyclodextrin and l-arginine by computational simulation studies: Preparation and characterization of supramolecular complexes. J. Mol. Liq. 2018, 259, 55-64. [CrossRef]

19. Méndez, S.G.; Otero Espinar, F.J.; Alvarez, A.L.; Longhi, M.R.; Quevedo, M.A.; Zoppi, A. Ternary complexation of benzoic acid with $\beta$-cyclodextrin and aminoacids. Experimental and theoretical studies. J. Incl. Phenom. Macrocycl. Chem. 2016, 85, 33-48. [CrossRef]

20. Singh, S.K.; Srinivasan, K.K.; Singare, D.S.; Gowthamarajan, K.; Prakash, D. Formulation of ternary complexes of glyburide with hydroxypropyl- $\beta$-cyclodextrin and other solubilizing agents and their effect on release behavior of glyburide in aqueous and buffered media at different agitation speeds. Drug Dev. Ind. Pharm. 2012, 38, 1328-1336. [CrossRef] [PubMed]

21. Vakani, S.S.; Kajwe, A.; Suvarna, V.; Sherje, A.P. Influence of auxiliary agents on solubility and dissolution profile of repaglinide with hydroxypropyl- $\beta$-cyclodextrin: Inclusion complex formation and its solid-state characterization. J. Incl. Phenom. Macrocycl. Chem. 2015, 83, 239-250. [CrossRef]

22. Suvarna, V.; Kajwe, A.; Murahari, M.; Pujar, G.V.; Inturi, B.K.; Sherje, A.P. Inclusion Complexes of Nateglinide with HP- $\beta-C D$ and L-Arginine for Solubility and Dissolution Enhancement: Preparation, Characterization, and Molecular Docking Study. J. Pharm. Innov. 2017, 12, 168-181. [CrossRef]

23. Jadhav, P.; Petkar, B.; Pore, Y.; Kulkarni, A.; Burade, K. Physicochemical and molecular modeling studies of cefixime-L-argininecyclodextrin ternary inclusion compounds. Carbohydr. Polym. 2013, 98, 1317-1325. [CrossRef]

24. Dan Córdoba, A.V.; Aiassa, V.; Longhi, M.R.; Quevedo, M.A.; Zoppi, A. Improved Activity of Rifampicin against Biofilms of Staphylococcus aureus by Multicomponent Complexation. AAPS PharmSciTech 2020, 21, 163. [CrossRef] [PubMed]

25. Conde Penedo, A.; Díaz Tomé, V.; Fernández Ferreiro, A.; González Barcia, M.; Otero Espinar, F.J. Enhancement in corneal permeability of riboflavin using cyclodextrin derivates complexes as a previous step to transepithelial cross-linking. Eur. J. Pharm. Biopharm. 2021, 162, 12-22. [CrossRef] [PubMed]

26. Mora, P.C.; Cirri, M.; Allolio, B.; Carli, F.; Mura, P. Enhancement of dehydroepiandrosterone solubility and bioavailability by ternary complexation with $\alpha$-cyclodextrin and glycine. J. Pharm. Sci. 2003, 92, 2177-2184. [CrossRef] [PubMed]

27. Piel, G.; Pirotte, B.; Delneuville, I.; Neven, P.; Llabres, G.; Delarge, J.; Delattre, L. Study of the Influence of Both Cyclodextrins and L-Lysine on the Aqueous Solubility of Nimesulide; Isolation and Characterization of Nimesulide-L-Lysine-Cyclodextrin Complexes. J. Pharm. Sci. 1997, 86, 475-480. [CrossRef] [PubMed]

28. Piette, M.; Evrard, B.; Frankenne, F.; Chiap, P.; Bertholet, P.; Castagne, D.; Foidart, J.-M.; Delattre, L.; Piel, G. Pharmacokinetic study of a new synthetic MMP inhibitor (Ro 28-2653) after IV and oral administration of cyclodextrin solutions. Eur. J. Pharm. Sci. Off. J. Eur. Fed. Pharm. Sci. 2006, 28, 189-195. [CrossRef] [PubMed]

29. Sauceau, M.; Rodier, E.; Fages, J. Preparation of inclusion complex of piroxicam with cyclodextrin by using supercritical carbon dioxide. J. Supercrit. Fluids 2008, 47, 326-332. [CrossRef]

30. Banchero, M.; Manna, L. The use of lysine to enhance the supercritical complexation of ketoprofen and cyclodextrins. J. Supercrit. Fluids 2012, 67, 76-83. [CrossRef]

31. Cerutti, J.P.; Quevedo, M.A.; Buhlman, N.; Longhi, M.R.; Zoppi, A. Synthesis and characterization of supramolecular systems containing nifedipine, $\beta$-cyclodextrin and aspartic acid. Carbohydr. Polym. 2019, 205, 480-487. [CrossRef]

32. Ponce-Ponte, M.; Aloisio, C.; Romero-Guerra, D.M.; Gracia-Vásquez, S.; Garnero, C.; Longhi, M. Binary and ternary complexes of norfloxacin to improve the solubility of the active pharmaceutical ingredient. Ther. Deliv. 2018, 9, 639-652. [CrossRef] 
33. Aiassa, V.; Zoppi, A.; Becerra, M.C.; Albesa, I.; Longhi, M.R. Enhanced inhibition of bacterial biofilm formation and reduced leukocyte toxicity by chloramphenicol: $\beta$-cyclodextrin:N-acetylcysteine complex. Carbohydr. Polym. 2016, 152, 672-678. [CrossRef]

34. Cerutti, J.P.; Aiassa, V.; Fernández, M.A.; Longhi, M.R.; Quevedo, M.A.; Zoppi, A. Structural, physicochemical and biological characterization of chloramphenicol multicomponent complexes. J. Mol. Liq. 2021, 331, 115761. [CrossRef]

35. Zoppi, A.; Buhlman, N.; Cerutti, J.P.; Longhi, M.R.; Aiassa, V. Influence of proline and $\beta$-Cyclodextrin in ketoconazole physicochemical and microbiological performance. J. Mol. Struct. 2019, 1176, 470-477. [CrossRef]

36. Zoppi, A.; Bartolilla, A.; Longhi, M.R.; Aiassa, V. Simultaneous improvement of ketoconazole solubility, antifungal and antibiofilm activity by multicomponent complexation. Ther. Deliv. 2020, 11, 701-712. [CrossRef] [PubMed]

37. Rakkaew, P.; Suksiriworapong, J.; Chantasart, D. $\beta$-Cyclodextrin-based ternary complexes of haloperidol and organic acids: The effect of organic acids on the drug solubility enhancement. Pharm. Dev. Technol. 2018, 23, 715-722. [CrossRef] [PubMed]

38. Londhe, V.Y.; Pawar, A.; Kundaikar, H. Studies on spectral characterization and solubility of hydroxypropyl $\beta$-cyclodextrin/iloperidone binary and ternary complexes using different auxiliary agents. J. Mol. Struct. 2020, 1220, 128615. [CrossRef]

39. Kurkov, S.V.; Loftsson, T. Cyclodextrins. Int. J. Pharm. 2013, 453, 167-180. [CrossRef]

40. Jug, M.; Mennini, N.; Kövér, K.E.; Mura, P. Comparative analysis of binary and ternary cyclodextrin complexes with econazole nitrate in solution and in solid state. J. Pharm. Biomed. Anal. 2014, 91, 81-91. [CrossRef]

41. Ribeiro, L.; Carvalho, R.A.; Ferreira, D.C.; Veiga, F.J.B. Multicomponent complex formation between vinpocetine, cyclodextrins, tartaric acid and water-soluble polymers monitored by NMR and solubility studies. Eur. J. Pharm. Sci. 2005, 24, 1-13. [CrossRef]

42. Patel, M.; Hirlekar, R. Multicomponent cyclodextrin system for improvement of solubility and dissolution rate of poorly water soluble drug. Asian, J. Pharm. Sci. 2019, 14, 104-115. [CrossRef]

43. Fenyvesi, E.; Vikmon, M.; Szeman, J.; Redenti, E.; Delcanale, M.; Ventura, P.; Szejtli, J. Interaction of hydroxy acids with $\beta$-cyclodextrin. J. Incl. Phenom. 1999, 33, 339-344. [CrossRef]

44. Mura, P.; Mennini, N.; Kosalec, I.; Furlanetto, S.; Orlandini, S.; Jug, M. Amidated pectin-based wafers for econazole buccal delivery: Formulation optimization and antimicrobial efficacy estimation. Carbohydr. Polym. 2015, 121, 231-240. [CrossRef]

45. Pokharkar, V.; Khanna, A.; Venkatpurwar, V.; Dhar, S.; Mandpe, L. Ternary complexation of carvedilol, $\beta$-cyclodextrin and citric acid for mouth-dissolving tablet formulation. Acta Pharm. 2009, 59, 121-132. [CrossRef] [PubMed]

46. Zhang, X.; Zou, M.; Li, S.; Chen, X.; Zhong, D. Bioavailability of clarithromycin cyclodextrin ternary complexes upon oral administration to healthy beagle dogs. Drug Dev. Ind. Pharm. 2008, 34, 1048-1053. [CrossRef] [PubMed]

47. Aldawsari, H.M.; Badr-Eldin, S.M. Enhanced pharmacokinetic performance of dapoxetine hydrochloride via the formulation of instantly-dissolving buccal films with acidic $\mathrm{pH}$ modifier and hydrophilic cyclodextrin: Factorial analysis, in vitro and in vivo assessment. J. Adv. Res. 2020, 24, 281-290. [CrossRef]

48. Yuvaraja, K.; Khanam, J. Enhancement of carvedilol solubility by solid dispersion technique using cyclodextrins, water soluble polymers and hydroxyl acid. J. Pharm. Biomed. Anal. 2014, 96, 10-20. [CrossRef]

49. Chantasart, D.; Rakkaew, P. Preparation and characterization of dry $\beta$-cyclodextrin-based ternary complexes of haloperidol and lactic acid for drug delivery. J. Drug Deliv. Sci. Technol. 2019, 52, 73-82. [CrossRef]

50. Barillaro, V.; Bertholet, P.; de Hassonville, S.H.; Ziemons, E.; Evrard, B.; Delattre, L.; Piel, G. Effect of acidic ternary compounds on the formation of miconazole/cyclodextrin inclusion complexes by means of supercritical carbon dioxide. J. Pharm. Pharm. Sci. 2004, 7, 378-388. [PubMed]

51. Barillaro, V.; Evrard, B.; Delattre, L.; Piel, G. Oral bioavailability in pigs of a miconazole $\gamma /$ hydroxypropyl- $\gamma$-cyclodextrin/Ltartaric acid inclusion complex produced by supercritical carbon dioxide processing. AAPS J. 2005, 7, E149-E155. [CrossRef]

52. Mura, P.; Faucci, M.T.; Manderioli, A.; Bramanti, G. Multicomponent systems of econazole with hydroxyacids and cyclodextrins. J. Incl. Phenom. 2001, 39, 131-138. [CrossRef]

53. Faucci, M.T.; Melani, F.; Mura, P. 1H-NMR and molecular modelling techniques for the investigation of the inclusion complex of econazole with $\alpha$-cyclodextrin in the presence of malic acid. J. Pharm. Biomed. Anal. 2000, 23, 25-31. [CrossRef]

54. Zhang, X.; Zhang, Y.; Zhong, D.; Chen, Y.; Li, S. Investigation and physicochemical characterization of clarithromycin-citric acid-cyclodextrins ternary complexes. Drug Dev. Ind. Pharm. 2007, 33, 163-171. [CrossRef] [PubMed]

55. Esclusa-Díaz, M.T.; Gayo-Otero, M.; Pérez-Marcos, M.B.; Vila-Jato, J.L.; Torres-Labandeira, J.J. Preparation and evaluation of ketoconazole- $\beta$-cyclodextrin multicomponent complexes. Int. J. Pharm. 1996, 142, 183-187. [CrossRef]

56. Chiesi-villa, A.; Rizzoli, C.; Amari, G.; Delcanale, M.; Redenti, E.; Ventura, P. The Crystal Structure of the Inclusion Complex of the Sodium Salt of Piroxicam with $\beta$-cyclodextrin. Supramol. Chem 1998, 10, 111-119. [CrossRef]

57. Lin, S.-Z.; Wouessidjewe, D.; Poelman, M.-C.; Duchêne, D. Indomethacin and cyclodextrin complexes. Int. J. Pharm. 1991, 69, 211-219. [CrossRef]

58. Ungell, A.-L. In Vitro Absorption Studies and Their Relevance to Absorption from the GI Tract. Drug Dev. Ind. Pharm. 1997, 23, 879-892. [CrossRef]

59. Gladys, G.; Claudia, G.; Marcela, L. The effect of $\mathrm{pH}$ and triethanolamine on sulfisoxazole complexation with hydroxypropyl- $\beta$ cyclodextrin. Eur. J. Pharm. Sci. 2003, 20, 285-293. [CrossRef]

60. Maitre, M.M.; Longhi, M.R.; Granero, G.G. Ternary complexes of flurbiprofen with HP- $\beta$-CD and ethanolamines characterization and transdermal delivery. Drug Dev. Ind. Pharm. 2007, 33, 311-326. [CrossRef] [PubMed]

61. Cheong, H.-A.; Choi, H.-K. Enhanced Percutaneous Absorption of Piroxicam via Salt Formation with Ethanolamines. Pharm. Res. 2002, 19, 1375-1380. [CrossRef] [PubMed] 
62. Garnero, C.; Longhi, M. Study of ascorbic acid interaction with hydroxypropyl- $\beta$-cyclodextrin and triethanolamine, separately and in combination. J. Pharm. Biomed. Anal. 2007, 45, 536-545. [CrossRef]

63. Granero, G.E.; Maitre, M.M.; Garnero, C.; Longhi, M.R. Synthesis, characterization and in vitro release studies of a new acetazolamide-HP- $\beta$-CD-TEA inclusion complex. Eur. J. Med. Chem. 2008, 43, 464-470. [CrossRef]

64. Palma, S.D.; Tartara, L.I.; Quinteros, D.; Allemandi, D.A.; Longhi, M.R.; Granero, G.E. An efficient ternary complex of acetazolamide with HP-B-CD and TEA for topical ocular administration. J. Control. Release 2009, 138, 24-31. [CrossRef]

65. Mora, M.J.; Petiti, J.P.; Longhi, M.R.; Torres, A.I.; Granero, G.E. Intestinal uptake and toxicity evaluation of acetazolamide and its multicomponent complexes with hidroxypropyl- $\beta$-cyclodextrin in rats. Int. J. Pharm. 2015, 478, 258-267. [CrossRef]

66. Mora, M.J.; Longhi, M.R.; Granero, G.E. Synthesis and characterization of binary and ternary complexes of diclofenac with a methyl- $\beta-C D$ and monoethanolamine and in vitro transdermal evaluation. Eur. J. Med. Chem. 2010, 45, 4079-4088. [CrossRef]

67. De Melo, P.N.; Barbosa, E.G.; De Caland, L.B.; Carpegianni, H.; Garnero, C.; Longhi, M.; De Freitas Fernades-Pedrosa, M.; Da Silva-Júnior, A.A. Host-guest interactions between benznidazole and beta-cyclodextrin in multicomponent complex systems involving hydrophilic polymers and triethanolamine in aqueous solution. J. Mol. Liq. 2013, 186, 147-156. [CrossRef]

68. De Melo, P.N.; Barbosa, E.G.; Garnero, C.; de Caland, L.B.; Fernandes-Pedrosa, M.F.; Longhi, M.R.; da Silva-Júnior, A.A. Interaction pathways of specific co-solvents with hydroxypropyl- $\beta$-cyclodextrin inclusion complexes with benznidazole in liquid and solid phase. J. Mol. Liq. 2016, 223, 350-359. [CrossRef]

69. Barbosa, J.A.A.; Zoppi, A.; Quevedo, M.A.; de Melo, P.N.; de Medeiros, A.S.A.; Streck, L.; de Oliveira, A.R.; Fernandes-Pedrosa, M.F.; Longhi, M.R.; da Silva-Júnior, A.A. Triethanolamine stabilization of methotrexate- $\beta$-cyclodextrin interactions in ternary complexes. Int. J. Mol. Sci. 2014, 15, 17077-17099. [CrossRef] [PubMed]

70. Ribeiro, L.; Loftsson, T.; Ferreira, D.; Veiga, F. Investigation and physicochemical characterization of vinpocetine-sulfobutyl ether $\beta$-cyclodextrin binary and ternary complexes. Chem. Pharm. Bull. 2003, 51, 914-922. [CrossRef]

71. Loftsson, T.; Jarho, P.; Másson, M.; Järvinen, T. Cyclodextrins in drug delivery. Expert Opin. Drug Deliv. 2005, 2, 335-351. [CrossRef]

72. Phadke, C.; Sharma, J.; Sharma, K.; Bansal, A.K. Effect of Variability of Physical Properties of Povidone K30 on Crystallization and Drug-Polymer Miscibility of Celecoxib-Povidone K30 Amorphous Solid Dispersions. Mol. Pharm. 2019, 16, 4139-4148. [CrossRef] [PubMed]

73. Sathigari, S.K.; Radhakrishnan, V.K.; Davis, V.A.; Parsons, D.L.; Babu, R.J. Amorphous-state characterization of efavirenz-polymer hot-melt extrusion systems for dissolution enhancement. J. Pharm. Sci. 2012, 101, 3456-3464. [CrossRef]

74. Madhavi, B.B.; Kusum, B.; Chatanya, C.K.; Madhu, M.N.; Harsha, V.S.; Banji, D. Dissolution enhancement of efavirenz by solid dispersion and PEGylation techniques. Int. J. Pharm. Investig. 2011, 1, 29-34. [CrossRef]

75. Vieira, A.C.C.; Ferreira Fontes, D.A.; Chaves, L.L.; Alves, L.D.S.; de Freitas Neto, J.L.; de La Roca Soares, M.F.; Soares-Sobrinho, J.L.; Rolim, L.A.; Rolim-Neto, P.J. Multicomponent systems with cyclodextrins and hydrophilic polymers for the delivery of Efavirenz. Carbohydr. Polym. 2015, 130, 133-140. [CrossRef] [PubMed]

76. Ghosh, A.; Biswas, S.; Ghosh, T. Preparation and Evaluation of Silymarin $\beta$-cyclodextrin Molecular Inclusion Complexes. J. Young Pharm. 2011, 3, 205-210. [CrossRef]

77. Kaushik, S.; Verma, R.; Purohit, D.; Pandey, P.; Kumar, M.; Kumari, B.; Kaushik, D. Development of binary and ternary complex of cefuroxime axetil with cyclodextrin for improving pharmaceutical characteristics. Int. J. Appl. Pharm. 2020, 12, $107-117$. [CrossRef]

78. Shah, M.; Pore, Y.; Dhawale, S.; Burade, K.; Kuchekar, B. Physicochemical characterization of spray dried ternary micro-complexes of cefuroxime axetil with hydroxypropyl- $\beta$-cyclodextrin. J. Incl. Phenom. Macrocycl. Chem. 2013, 76, 391-401. [CrossRef]

79. Valero, M.; Tejedor, J.; Rodríguez, L.J. Encapsulation of nabumetone by means of -drug: ( $\beta$-cyclodextrin)2:polyvinylpyrrolidone ternary complex formation. J. Lumin. 2007, 126, 297-302. [CrossRef]

80. Shah, M.; Karekar, P.; Sancheti, P.; Vyas, V.; Pore, Y. Effect of PVP K30 and/or L-arginine on stability constant of etoricoxib-HP $\beta C D$ inclusion complex: Preparation and characterization of etoricoxib-HP $\beta C D$ binary system. Drug Dev. Ind. Pharm. 2009, 35, 118-129. [CrossRef]

81. Bejaoui, M.; Galai, H.; Amara, A.B.H.; Ben Rhaiem, H. Formation of Water Soluble and Stable Amorphous Ternary System: Ibuprofen/ $\beta$-Cyclodextrin/PVP. Glas. Phys. Chem. 2019, 45, 580-588. [CrossRef]

82. Loh, Z.H.; Samanta, A.K.; Sia Heng, P.W. Overview of milling techniques for improving the solubility of poorly water-soluble drugs. Asian J. Pharm. Sci. 2015, 10, 255-274. [CrossRef]

83. Cheung, R.C.; Ng, T.B.; Wong, J.H.; Chan, W.Y. Chitosan: An Update on Potential Biomedical and Pharmaceutical Applications. Mar. Drugs 2015, 13, 5156-5186. [CrossRef] [PubMed]

84. Chen, G.; Mi, J.; Wu, X.; Luo, C.; Li, J.; Tang, Y.; Li, J. Structural features and bioactivities of the chitosan. Int. J. Biol. Macromol. 2011, 49, 543-547. [CrossRef]

85. Sarvaiya, J.; Agrawal, Y.K. Chitosan as a suitable nanocarrier material for anti-Alzheimer drug delivery. Int. J. Biol. Macromol. 2015, 72, 454-465. [CrossRef]

86. Dehousse, V.; Garbacki, N.; Jaspart, S.; Castagne, D.; Piel, G.; Colige, A.; Evrard, B. Comparison of chitosan/siRNA and trimethylchitosan/siRNA complexes behaviour in vitro. Int. J. Biol. Macromol. 2010, 46, 342-349. [CrossRef]

87. Benediktsdóttir, B.E.; Baldursson, Ó.; Másson, M. Challenges in evaluation of chitosan and trimethylated chitosan (TMC) as mucosal permeation enhancers: From synthesis to in vitro application. J. Control. Release 2014, 173, 18-31. [CrossRef] [PubMed] 
88. Patel, P.; Agrawal, Y.K.; Sarvaiya, J. Cyclodextrin based ternary system of modafinil: Effect of trimethyl chitosan and polyvinylpyrrolidone as complexing agents. Int. J. Biol. Macromol. 2016, 84, 182-188. [CrossRef]

89. Chadha, R.; Arora, P.; Bhandari, S. Polymorphic Forms of Lamivudine: Characterization, Estimation of Transition Temperature, and Stability Studies by Thermodynamic and Spectroscopic Studies. ISRN Thermodyn. 2012, 2012, 671027. [CrossRef]

90. Porwal, A.; Dwivedi, H.; Pathak, K. Gastroretentive bilayer film for sustained release of atorvastatin calcium and immediate release of amlodipine besylate: Pharmaceutical, pharmacokinetic evaluation, and IVIVC. Pharm. Dev. Technol. 2020, 25, 416-431. [CrossRef]

91. Benavente-García, O.; Castillo, J. Update on Uses and Properties of Citrus Flavonoids: New Findings in Anticancer, Cardiovascular, and Anti-inflammatory Activity. J. Agric. Food Chem. 2008, 56, 6185-6205. [CrossRef] [PubMed]

92. Anwer, M.K.; Jamil, S.; Ansari, M.J.; Al-Shdefat, R.; Ali, B.E.; Ganaie, M.A.; Abdel-Kader, M.S.; Shakeel, F. Water soluble binary and ternary complexes of diosmin with $\beta$-cyclodextrin: Spectroscopic characterization, release studies and anti-oxidant activity. J. Mol. Liq. 2014, 199, 35-41. [CrossRef]

93. Loh, G.O.K.; Tan, Y.T.F.; Peh, K.K. Effect of HPMC concentration on $\beta$-cyclodextrin solubilization of norfloxacin. Carbohydr. Polym. 2014, 101, 505-510. [CrossRef] [PubMed]

94. Amrite, A.; Pugazhenthi, V.; Cheruvu, N.; Kompella, U. Delivery of celecoxib for treating diseases of the eye: Influence of pigment and diabetes. Expert. Opin. Drug Deliv. 2010, 7, 631-645. [CrossRef] [PubMed]

95. Amrite, A.C.; Kompella, U.B. Celecoxib inhibits proliferation of retinal pigment epithelial and choroid-retinal endothelial cells by a cyclooxygenase-2-independent mechanism. J. Pharmacol. Exp. Ther. 2008, 324, 749-758. [CrossRef] [PubMed]

96. Ayalasomayajula, S.P.; Kompella, U.B. Celecoxib, a selective cyclooxygenase-2 inhibitor, inhibits retinal vascular endothelial growth factor expression and vascular leakage in a streptozotocin-induced diabetic rat model. Eur. J. Pharmacol. 2003, 458, 283-289. [CrossRef]

97. Raghava, S.; Hammond, M.; Kompella, U.B. Periocular routes for retinal drug delivery. Expert Opin. Drug Deliv. 2004, 1, 99-114. [CrossRef]

98. Jansook, P.; Kulsirachote, P.; Asasutjarit, R.; Loftsson, T. Development of celecoxib eye drop solution and microsuspension: A comparative investigation of binary and ternary cyclodextrin complexes. Carbohydr. Polym. 2019, 225, 115209. [CrossRef]

99. Scott, J.E.; Heatley, F. Hyaluronan forms specific stable tertiary structures in aqueous solution: A 13C NMR study. Proc. Natl. Acad. Sci. USA 1999, 96, 4850-4855. [CrossRef]

100. Jansook, P.; Pichayakorn, W.; Muankaew, C.; Loftsson, T. Cyclodextrin-poloxamer aggregates as nanocarriers in eye drop formulations: Dexamethasone and amphotericin B. Drug Dev. Ind. Pharm. 2016, 42, 1446-1454. [CrossRef]

101. Yokoyama, M. Polymeric micelles as a new drug carrier system and their required considerations for clinical trials. Expert. Opin. Drug Deliv. 2010, 7, 145-158. [CrossRef]

102. Alvarez-Lorenzo, C.; Rey-Rico, A.; Brea, J.; Loza, M.I.; Concheiro, A.; Sosnik, A. Inhibition of P-glycoprotein pumps by PEO-PPO amphiphiles: Branched versus linear derivatives. Nanomedicine 2010, 5, 1371-1383. [CrossRef]

103. Lee, J.-H.; Kim, H.-L.; Lee, M.H.; You, K.E.; Kwon, B.-J.; Seo, H.J.; Park, J.-C. Asiaticoside enhances normal human skin cell migration, attachment and growth in vitro wound healing model. Phytomedicine 2012, 19, 1223-1227. [CrossRef]

104. Soe, H.M.H.; Chamni, S.; Mahalapbutr, P.; Kongtaworn, N.; Rungrotmongkol, T.; Jansook, P. The investigation of binary and ternary sulfobutylether- $\beta$-cyclodextrin inclusion complexes with asiaticoside in solution and in solid state. Carbohydr. Res. 2020, 498, 108190. [CrossRef] [PubMed]

105. Bey, E.A.; Bentle, M.S.; Reinicke, K.E.; Dong, Y.; Yang, C.-R.; Girard, L.; Minna, J.D.; Bornmann, W.G.; Gao, J.; Boothman, D.A. An NQO1- and PARP-1-mediated cell death pathway induced in non-small-cell lung cancer cells by $\beta$-lapachone. Proc. Natl. Acad. Sci. USA 2007, 104, 11832-11837. [CrossRef]

106. Bentle, M.S.; Reinicke, K.E.; Bey, E.A.; Spitz, D.R.; Boothman, D.A. Calcium-dependent Modulation of Poly(ADP-ribose) Polymerase-1 Alters Cellular Metabolism and DNA Repair. J. Biol. Chem. 2006, 281, 33684-33696. [CrossRef]

107. Bentle, M.S.; Reinicke, K.E.; Dong, Y.; Bey, E.A.; Boothman, D.A. Nonhomologous end joining is essential for cellular resistance to the novel antitumor agent, $\beta$-lapachone. Cancer Res. 2007, 67, 6936-6945. [CrossRef] [PubMed]

108. Nasongkla, N.; Wiedmann, A.F.; Bruening, A.; Beman, M.; Ray, D.; Bornmann, W.G.; Boothman, D.A.; Gao, J. Enhancement of Solubility and Bioavailability of $\beta$-Lapachone Using Cyclodextrin Inclusion Complexes. Pharm. Res. 2003, 20, 1626-1633. [CrossRef] [PubMed]

109. Seoane, S.; Díaz-Rodríguez, P.; Sendon-Lago, J.; Gallego, R.; Pérez-Fernández, R.; Landin, M. Administration of the optimized $\beta$-Lapachone-poloxamer-cyclodextrin ternary system induces apoptosis, DNA damage and reduces tumor growth in a human breast adenocarcinoma xenograft mouse model. Eur. J. Pharm. Biopharm. 2013, 84, 497-504. [CrossRef] [PubMed] 